\title{
The Association Between Reading and Emotional Development: A Systematic Review
}

\author{
Federico Batini ${ }^{1}$, Valerio Luperini ${ }^{1}$, Eleonora $\mathrm{Cei}^{1}{ }^{1}$, Diego $\operatorname{Izzo}^{1}$, Giulia Toti ${ }^{1}$ \\ ${ }^{1}$ Department of Philosophy, Social \& Human Sciences and Education, University of Perugia, Italy \\ Correspondence: Federico Batini, Department of Philosophy, Social \& Human Sciences and Education, University of \\ Perugia, Piazza G. Ermini, 1 - 06123 - Perugia, PG. E-mail: federico.batini@unipg.it
}

Received: October 22, 2020

Accepted: November 26, 2020

Online Published: December 6, 2020

doi:10.11114/jets.v9i1.5053

URL: https://doi.org/10.11114/jets.v9i1.5053

\begin{abstract}
Reading practice is associated with numerous psychological benefits. However, its influence over individual emotional dimensions has generally been underestimated by research. Only recently has it been recognized across different developmental stages but evidence is still scarce. The aim of this systematic review is to shed light over the association between reading and the several (and sometimes hardly distinguishable) socio-emotional constructs that we have identified in literature: interpersonal skills and prosocial behavior; emotional and behavioral symptoms; emotional regulation and expression; empathy and theory of mind; emotional knowledge and comprehension; and emotional responses. A total of 50 studies were analyzed, including all age groups, various settings, research drawings, and different emotional constructs in order to create a comprehensive view of the association between reading and emotions. Results show that overall reading practice has a positive impact on socio-emotional development, whatever its declination, regardless of age, gender or setting of implementation.
\end{abstract}

Keywords: reading; read-aloud; emotion; socio-emotional competence; emotional development

\section{Introduction}

Reading is based on interactive processes between the reader and the text (McCreary \& Marchant, 2017); indeed, while involved in this activity, the reader creates meaning and decides what information is essential. As underlined by McCreary and Marchant (2017), reading is closely linked to critical thinking (Abu-Shihab, 2011) and requires a great number of abilities. It fosters a better comprehension of information (Wallot, O'Brien, Haussmann, Kloos, \& Lyby, 2014) and the use of learning strategies (Lim, Bong, \& Woo, 2015). The cognitive benefits of reading are well known, for example, on expressive and receptive language (Mendelsohn et al., 2001), vocabulary learning and story comprehension (Bus, Takacs, \& Kegel, 2015; Dore et al., 2018) or problem-solving and communication (Murray \& Egan, 2014). However, although still scarce, recent empirical research has underlined that reading also has positive impacts on other abilities related to socioemotional competencies, in particular those identified with the label of "social understandings". These refer to the ability to understand and sympathize with others' emotions, cognitions and motivations, which is crucial to fostering the development of adaptive relational resources (Carpendale \& Lewis, 2006). Moreover, these elements are part of the broader area of socioemotional competence, that includes important skills needed to manage our inner states and to relate to others. These abilities are developed in responsive and safe environments that involve reading practices as a key instrument to support this growth (Santos, Fettig, \& Shaffer, 2012; Shonkoff \& Phillips, 2000).

\subsection{A difficult Concept to Define}

"Socioemotional competence" is an umbrella term. Under this label are often grouped many different psychological aspects that sometimes overlap each other, such as "social understandings", "empathy", "emotional intelligence", "Theory of mind". These are some of the most common concepts. However, even defining these singular terms can be complex. Unclear or divergent descriptions of empathy are common across research literature, as well as inconsistent means of measuring it (Gerdes, Segal, \& Lietz, 2010). However, before proceeding, we will try to set a definition for each of these concepts. With "Empathy" we mean a construct that includes affective (the emotional reaction toward or with a person or a character) and cognitive dimensions (the competence to assume others' perspective or imaging oneself in the place of another person or character) (Junker \& Jacquemin, 2017). Moreover, empathy is not an innate 
ability: instead, it is something that everyone can learn and practice in their environment (Stepien \& Baernstein, 2006). The concept of "Theory of mind" was introduced by Premack and Woodruff in 1978 and is meant as the ability to attribute mental states (thoughts, knowledge, hopes, emotions, desires) to oneself and others and to foresee one's own and others' behavior based on these states (Meins, Fernyhough, Arnott, \& Leekam, 2013). As regards to "Emotional Intelligence" we will refer to Bar-On model (2006), that describes this concept as a number of interrelated emotional and social skills associated to one's ability to understand and manage emotions, to relate with others, to adapt to different situations, to cope with personal and interpersonal problems and with daily challenges. These competencies have appeared to predict better physical and psychological health and better social and work performances (Bar-On, 2006). Keeping this complexity in mind, we chose to consider all these aspects in our research. Thus when using the terms "socioemotional development" or "competence" we will broadly refer to the general ability to understand and infer one's own and others' inner states, such as emotions, thoughts, desires, and motivations, and to flexibly implement the most appropriate behavior to respond, in an adaptive way, to singular interpersonal exchanges. This definition recalls Fonagy and Target's concept of "Reflective Function" (1997), that includes emotional and cognitive abilities implicated in our social interactions.

\subsection{Reading and Socioemotional Development}

Literature is crucial for empathy growth (Volpi, 2011). The relationship between reading and socioemotional development is clear over different lifetime periods and even in early childhood. Through shared book reading toddlers may form social bonds, closeness and attachment. In this overlap of social and emotional dimensions, toddlers begin to construct adaptive ways to communicate with adults and become involved in social processes. Written and oral stories build the framework to foster socio-emotional abilities for empathy and relationships (National Research Council, 1999). Thus, exposing children to books and stories promotes the acquisition of reading and emotional skills that, in turn, help them succeed in school and beyond (Ayotte et al., 2003; Elbaum \& Vaughn, 2001; Reschly, 2010). Research based on theory of mind tasks has shown that the more four to six-years-olds are exposed to reading experiences provided by their parents, the better they are at understanding that others might have different mental states from their own (Adrián, Clemente, Villanueva, \& Rieffe, 2005; Mar, Tackett, \& Moore, 2010). This association seems evident also in school-age children, even if studies on this life period are scarce (Kozak \& Recchia, 2019). One recent study on ten-year-olds revealed that reading literary fiction leads to a slight - but significant - increase in social understanding in comparison to reading popular fiction or nonfiction (Wulandini, Kuntoro, \& Handayani, 2018). Another study focused on primary school students (Batini, Bartolucci, \& Timpone, 2018) showed that an intensive training of reading aloud fostered an improvement in empathy and the ability to understand emotional responses to situations and circumstances. In regards to adulthood, research on university students (Mar, Oatley, Hirsh, dela Paz, \& Peterson, 2006; Mar, Oatley, \& Peterson, 2009; Mumper \& Gerrig, 2017) has shown positive associations between reading in one's free time and social understanding. Moreover, each reading experience has different characteristics; reading fiction, in particular, seems to stimulate more empathy than reading nonfiction texts, whereas reading literary books has shown to lead higher levels of empathy than popular texts and genre fiction (Djikic, Oatley, \& Moldoveanu, 2009; Kidd \& Castano, 2013, 2017). Also, first-person narrations are likely to foster empathy (Oatley, 1999), while approaching literary fiction through digital formats seems to decrease this effect (Mangen \& Kuiken, 2014).

However, literature is not unanimous in supporting this sort of evidence and debate is still in course about the role of reading in emotional development. Some studies (Panero et al., 2016; Samur, Tops, \& Koole, 2018) fail to replicate Kidd and Castano's findings (2013) that reading literary fiction primes improvements in theory of mind skills, though underlining a positive association between familiarity with fiction and mentalizing.

On the other hand, a meta-analysis led by Dodell-Feder and Tamir (2018) on 14 studies strengthens the association between reading (specifically fiction reading compared to nonfiction reading) and social cognition improvement. This finding supports the evidence that fiction reading improves social cognition. However, it is not clear to what extent reading has a significant effect on emotional development, which is the underlying factor involved in this association. We will discuss this point in the next section.

\subsection{Theoretical Framework}

As illustrated by Kozak and Recchia (2019), several explanations have been provided to these findings. The first one is that reading is a simulation of the real world: by engaging with fiction, readers may undergo experiences vicariously through the protagonists' lives (Mar \& Oatley, 2008). Gerrig (1993) referred to this phenomenon as "transportation": the reader is transported in the world created by the author. Reading allows us to simulate characters' experiences in different situations and to understand their inner states. Indeed, successful social interactions are based on the ability of the individual to understand what others experience in a certain situation (Mar \& Oatley, 2008). A logical consequence of this statement is that the more characters a reader knows, the more he or she will become an expert of others' inner 
functioning: that is, social understanding skills are developed vicariously (Kozak \& Recchia, 2019).

Even if the simulation theory represents one of the most quoted ways to explain how underlying mechanisms work on the emotional experience of reading, some other processes could be substantially involved. A first example is given by Mumper and Gerrig (2019), who have theorized three main processes affecting the emotional content of the readers' narrative experience. Firstly, while we are reading, we draw some automatic inferences on the basis of a memory process called "resonance": when a character experiences a negative emotion or some kind of unpleasant situation, we experience the same emotion. This process is meant to give us a more detailed representation of the scene, drawing from long-term memory to empower the story's comprehension and involvement. Secondly, the mechanisms generating emotion and evaluation of reality affect the emotion we feel for the stories' characters: for example, unpleasantness or pleasantness, self or other responsibility, situational control and level of certainty or uncertainty about what will happen next. Thirdly, this narrative participation could decisively characterize the emotional experience of reading. If the story provides a scene in which there could be a potentially dangerous event in the plot, the narrative immersion leads us to switch on a kind of "mental warning" in which we experience the same (negative) emotions that we would feel if such a scenario were to occur in real life.

A third theory is related to the emotional states evoked during reading, so that a deeper emotional engagement may foster empathy growth. In this regard, adults who reported feeling emotionally transported by a story specifically written to induce warm feelings (such as sympathy or compassion), experienced more empathetic emotions while reading (Johnson, 2012).

A fourth theory focuses on readers' opportunities to infer characters' mental states. Since social understanding is based on the same ability to make inferences on others' inner states, reading fiction may hone readers' inference skills and, consequently, foster socioemotional development. Thus, identifying with a book character allows us to infer his or her inner thoughts, feelings, and plans could be a good training technique to implement the same expertise in the real world (Mar, Oatley, Djikic, \& Mullin, 2011; Mumper \& Gerrig, 2017).

Another interesting contribution regarding the development of social cognition through reading exposure comes from the Social Processes and Content Entrained by Narrative (SPaCEN) framework (Mar, 2018). This theory supposes that there are two ways in which reading stories can have a positive influence on the development of social skills. Firstly, stories can improve mental inferencing, the main tool to evoke and update the social mechanisms through which we understand and explain the social dimension of the world. Secondly, social cognition is affected by contents presented in the stories: when the stories explicitly talk about personal aspects of the characters (e.g. personality traits), we adapt our social schemas in order to apply them to the people we meet. In this regard, Gerrig (1993) observed that the social processes involved in the comprehension of the story (e.g. theory of mind, empathy/sympathy, social memory) are the same we use to put in place in real world comprehension.

\subsubsection{Our Theoretical Framework: A Summary}

We can therefore summarize that reading has substantial power over the many mechanisms that we have enclosed in the term "socioemotional competence". Reading simulates real life (Gerrig, 1993): readers experience the characters' emotional states in the stories and train themselves to grasp and understand their own and others' emotions in a better way (Mar \& Oatley, 2008). By coming into contact with the stories and the characters' emotions, a resonance process is activated in which we bring our previous experiences closer to the events of the story, giving meaning to the reading in a clearer and more precise way, living the underlying emotions more intensively and decisively characterizing the reading experience in general (Mumper \& Gerrig, 2019).

This immersion in reading enables the reader's empathy (Johnson, 2012) and the inference of other people's mental states. These are fundamental skills to adapt to the real world (Mar et. al, 2011; Mumper \& Gerrig, 2017). In line with this point, the SPaCEN explanation (Mar, 2018) also highlights how stories foster the development of our mental capacity and social cognition. These different contributions have as a key assumption that reading has a strong influence over emotions and are able to highlight various aspects of this association. Reading allows us to experience, know and recognize emotions, to understand and grasp our own and others' emotional states, as well as to re-propose these socio-interpersonal skills in real life, improving our emotional and behavioural skills and favouring a continuous adaptation to the environment.

\subsection{The Purpose of This Study}

Our study is rooted in the debate of literature about the role of reading in fostering emotional development. On the basis of the above theoretical considerations, the purpose of this study is to investigate the association between reading and emotional development across the recent psychological and educational literature, trying to add evidence to this still little explored research field. For this purpose, following an overview of the whole life path, with no any age restrictions, 
we collected empirical studies in which the association between reading and emotional development was explored, in order to investigate whether reading leads to improvements in emotional dimensions. As Kozak and Recchia (2019) discussed, there is a lack of studies concerning school-age: for this reason, our review tries to fill this gap by adding evidence of this life period.

\section{Method}

\subsection{Retrieval of Studies and Inclusion Criteria}

In order to obtain studies examining the effects of reading on emotions, the PICOS method was taken as a reference (Moher, Liberati, Tetzlaff, \& Altman, 2009). In this approach, each letter identifies an element of the research question: participants $(\mathrm{P})$, intervention $(\mathrm{I})$, comparisons $(\mathrm{C})$, outcomes $(\mathrm{O})$ and study design $(\mathrm{S})$. This method led us to define the research question in a structured way by establishing seven inclusion criteria.. The first criterion was to select articles published from 2011. This time range was chosen to focus on the most recent literature. A second criterion was to select peer-reviewed articles. All empirical studies were included: evidence based, studies based on qualitative analysis, observations or mixed methods; the purpose was to investigate the impact of all types of reading on emotions and this could be observed through numerous types of research. Moreover, since there are many different definitions and means of assessment related to emotional concepts (Gerdes et al., 2010), we decided to take into account different strategies to evaluate emotional development. Non-empirical studies were excluded. The third criterion for inclusion was language: contributions published in English, Italian, and Spanish were included, contributions published in other languages were excluded. Fourthly, in terms of populations considered, the analysis covered all ages, with no age restrictions. Studies conducted on a population with a learning disability or learning disorder were excluded from the analysis in order to focus the analysis on the impact of reading activity on emotional factors, while trying to limit the influence of other variables. Fifth, as far as the setting is concerned, all studies with home environments, labs, schools, universities or other services with an explicit educational purpose as their setting were included. The analysis focused on reading in a broad sense, and therefore no limitations were placed on the modalities and characteristics in which this activity could be carried out. As a sixth criterion, studies involving the use of individual or shared, silent or loud reading were included: reading training, reading sessions and educational laboratory based on reading. Studies that did not include reading interventions but assessed reading habits or language skills were also included. Therefore, socio-emotional development programs with an impact on reading performance were excluded. The use of reading through technological media was excluded. Studies including learning programs of a second language were also excluded. The same procedure was adopted for the emotional dimension; studies that investigated emotional development, emotional intelligence, recognition of emotions were analyzed. We identified as the seventh criterion the inclusion of skills concerning these areas and excluding results different from the objective.

\subsection{Search strategies}

This analysis was carried out in May 2020 and was conducted using two electronic databases: ERIC and PsycInfo. The ERIC research input was: (reading OR reading aloud) AND (emotion OR empathy OR emotional intelligence) AND (emotional development OR understanding of emotions) NOT (diseases OR brain loss OR disability OR autism spectrum OR syndrome OR disorder) NOT (second language). The PsycInfo research input was: (reading OR oral reading OR reading aloud) AND (emotion OR emotional development) AND (empathy OR emotional intelligence OR recognize emotion) NOT (diseases OR brain loss OR disability OR autism spectrum OR syndrome OR disorder) NOT (second language). This method of analysis has been used in previous research (Barquero, Davis, \& Cutting, 2014; Salceda, Alonso, \& Castilla-Earls, 2014). As shown in Figure 1, the ERIC search produced 558 results and PsycInfo search produced 220 results: 6 duplicate items were removed and the result was 772 . The first analysis that was carried out was based on reading the title and the abstract of each article to identify those relevant to our criteria: 673 contributions were excluded because they did not meet the inclusion criteria, the remaining 99 articles were included. Subsequently a full reading of the articles was carried out, 33 articles that did not meet the inclusion criteria were excluded and 16 theoretical articles were used for the drafting of the introduction. The bibliographic research led to a final total of 50 studies that met the criteria for inclusion in the review of the descriptive literature. 


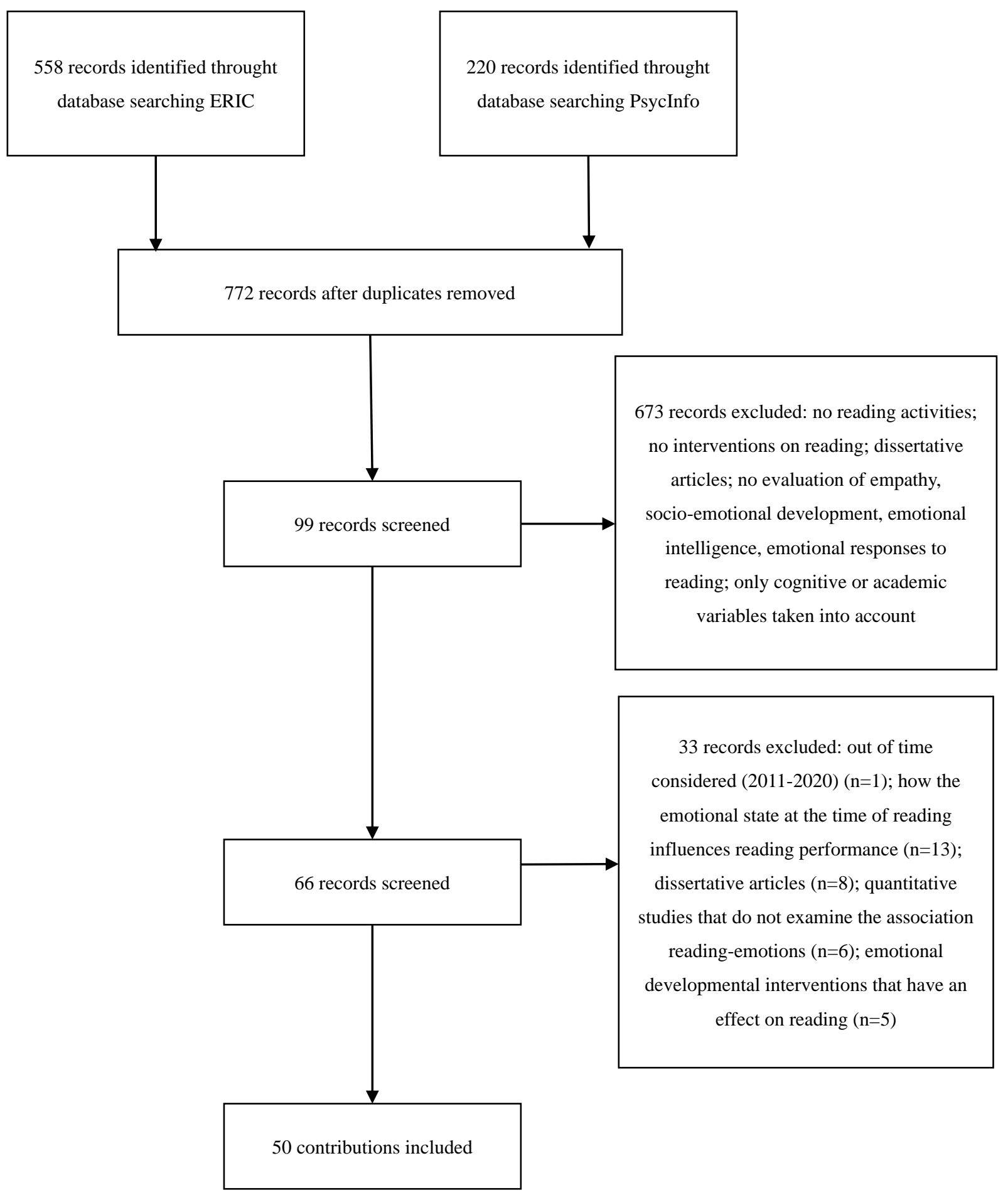

Figure 1. Study selection

\subsection{Data Collection}

The final articles (50) that have been analyzed are presented and discussed in the results. The information describing the area of intervention, the research design, the samples, the evaluation tools, the intervention and the outcomes is presented in Appendix A, B and C. Ten of the fifty articles are qualitative studies, three are case studies and two are neuroimaging studies. As regards the age group considered, Appendix A collects 13 articles including a sample of children (of which two articles had as participants children from kindergarten to primary school), Appendix B collects 24 articles with a sample of school age participants (from primary to upper high school), Appendix C collects 13 articles with a sample of adults.

\section{Results}


In line with the assumptions of the review, all the studies analyzed focused on reading and emotions variables as objects of investigation. A descriptive analysis of the results will be presented in relation to the reference age and the research design used in the studies; this description will be divided according to the three reference evolutionary periods: childhood, school-age, adulthood. Further information about research designs is reported in Tables 1, 2 and 3 . Subsequently, the overall results related to reading components are presented. After that, the focus will be on the results related to emotional constructs.

\subsection{Descriptive Results}

The samples of the total 50 studies cover an overall age range from 18 months to 73 years old. These data are based on the youngest and oldest ages considered, excluding studies that did not indicate the age range.

\subsubsection{Childhood}

Regarding the Childhood sample (see Appendix A), out of a total of 13 articles, 2 studies were identified on participants in the nursery age group (Betawi, 2015; Drummond, Paul, Waugh, Hammond, \& Brownell, 2014), 9 studies on a sample of participants in the Preschool age group (e.g. Aram, Deitcher, Shoshan, \& Ziv, 2017; Baker \& Rimm-Kaufman, 2014) and 2 studies following participants' growth from the preschool to primary school (Riquelme \& Montero, 2016; Riquelme, Munita, Jara, \& Montero, 2013). Of the total of 13 articles, 10 studies have a quantitative research design (of which 4 with control groups), 2 are longitudinal studies without a specific intervention and 1 study has a qualitative research design.

\subsubsection{School-Age}

In the School-age sample (see Appendix B), out of a total of 24 articles, 14 studies involved participants in the primary school (e.g. Angantyr, Hansen, Eklund, \& Malm, 2016; Beck, Kumschick, Eid, \& Klann-Delius, 2012; Brokamp, Houtveen, \& van de Grift, 2019), 5 studies enrolled participants in the middle school (e.g. Chisholm, Shelton, \& Sheffield, 2017). One of these latter studies followed the sample till the last years of high school (Dylman, Blomqvist, \& Champoux-Larsson, 2020). 5 studies focused on high school participants (e.g. Abdolrezapour \& Tavakoli, 2012; Boatright \& Allman, 2018). Of the total 24 articles, 17 studies have a quantitative research design, of which 3 are longitudinal; 10 studies use control groups. 4 papers are qualitative studies, of which one is longitudinal; 3 are case-studies.

\subsubsection{Adulthood}

Finally, concerning the Adulthood sample (see Appendix C), out of a total of 13 articles, 9 studies involved participants from the university (e.g. Glenn, 2012; Hoggan \& Cranton, 2015), and 4 studies enrolled samples of adult participants not belonging to an educational level (e.g. Altmann, Bohrn, Lubrich, Menninghaus, \& Jacobs, 2012). Of the total 13 articles, 4 studies have a quantitative research design, 5 studies have a qualitative research design, 2 studies use both quantitative and qualitative research designs and 2 are functional neuroimaging studies.

\subsection{Reading Components}

The analysis of the studies allowed us to report some results on the reading components. Out of a total of 50 studies, 10 studies did not implement any specific reading intervention, they evaluated the association between reading and socio-emotional competence in other ways: Baker (2013) for example, explored the association between numerous family literacy activities conducted by fathers and mothers with their children (such as storytelling, reading books, number of books provided) and the subsequent development of socio-cognitive skills in children; in contrast, other authors measured reading skills (e.g. Morgan et al., 2012; Undheim et al., 2011), reading habits (e.g. Dylman et al., 2020; Tabullo, Jiménez, \& García, 2018) and language skills (e.g. Beck et al., 2012) and their association with emotions. The other 40 studies implemented different reading interventions. Some studies conducted intensive reading training with long-term interventions; these studies implemented reading practices in various forms and modalities, such as individual reading (e.g. LaForge, Perron, Roy-Charland, Roy, \& Carignan, 2018), or reading aloud through mediated, shared or interactive modalities (e.g. Abdolrezapour \& Tavakoli, 2012; Betawi, 2015; Lysaker \& Tonge, 2013). Some research developed comparisons between various types of reading, in order to observe the most effective one on emotional variables (e.g. Riquelme \& Montero, 2016). Other research used sessions of individual or shared reading, sometimes based on a single moment (e.g. Angantyr et al., 2016; Chisholm et al., 2017), other times based on several moments limited in time (e.g. Schapira \& Aram, 2019). Finally, some studies have implemented educational workshops based on reading and discussion (e.g. Chisholm et al., 2017; Gordon, 2017).

The main contexts in which the studies were carried out are the school and educational environments, considered in all the developmental periods (e.g. Brokamp et al., 2019; Grazzani \& Ornaghi, 2011; Pytash, 2013; Venegas, 2019), and the family environment, particularly involved in the Childhood period (e.g. Baker, 2013; Drummond et al., 2014; Ferretti \& Bub, 2017; Schapira \& Aram, 2019). A further interesting clarification that emerged from the analysis of the results 
concerns the reading choices made by the studies that implemented an intervention. We observe the selection of books with multicultural aspects (Glenn, 2012; Gordon, 2017; Slay \& Morton, 2020; Tomé-Fernández et al., 2019), and books with relevant emotional content, with a greater frequency for reading with negative emotional contents (Altmann et al., 2012; Angantyr et al., 2016; Iacozza, Costa, \& Duñabeitia, 2017; Karniol, 2012). Some studies have chosen specific contents, such as disability (Venegas, 2019), bullying and suicide (Pytash, 2013) and relevant historical events (Chisholm et al., 2017).

\subsection{Categorization of the Emotional Constructs}

As mentioned above, under the label of "socio-emotional competence" are grouped many different concepts whose borders fade and are intertwined. This phenomenon is reflected by our results. Indeed, many articles use different names to refer to the same mental process (e.g. "social imagination" and "Theory of mind"); others focus on different, singular aspects of the same, wider, emotional concept (e.g. "cognitive empathy" vs "affective empathy"). In other cases, some wider emotional constructs overlap one another (e.g. the emotional intelligence, among its several aspects, comprehends also empathetic skills, overlapping the construct of "Empathy").

This "Babilonia Tower" is reflected even in the tools used to assess emotional components. Sometimes the same aspects are evaluated with different instruments. For example, beyond the qualitative studies, the most used tools for empathy are at least four: the Interpersonal Reactivity Index (IRI; Davis, 1983) was used in 5 studies, followed by the Empathy Quotient Test (Baron-Cohen \& Wheelwright, 2004) (three studies), the Griffith Empathy Measure-Parent Report (GEM-PR; Hunter \& Bech, 2003) (three studies), and the Reading the Mind in the Eyes Task (RMET; Baron-Cohen et al., 2001) (two studies). With the IRI, the Test of Emotion Comprehension (TEC) (Pons \& Harris, 2000) is the most used instrument (five studies investigating emotional knowledge).

In order to better sort out our findings, we decided to decompose the wider emotional concepts and to focus on the singular socio-emotional aspects evaluated by each study, grouping our sample of 50 articles on the base of the same area of assessment (see Tables 1, 2 and 3). Referring to the theoretical background, we focused mainly on constructs associated with the emotional experience elicited by reading and the ability to infer, recognize and understand one's own and others' emotions and to relate to the environment in an adaptive and socially appropriate way. Thus, six labels were inferred: (a) Social-relational and interpersonal skills (prosocial behavior, cooperation, assertiveness, adaptability, social awareness); (b) Emotional and behavioral problems (such as anxiety and depression, emotional maladjustment, social problems, conduct problems, aggressive behavior, ADHD symptoms); (c) Emotional and behavioral adaptive competences (emotional regulation and expression, self-control, impulse control, emotional stability, self-esteem); (d) Ability to understand and sympathize with others' mind (empathy, theory of mind, understanding of emotions, social imagination, social understanding, sympathy, perspective-taking); (e) Emotional knowledge (emotional vocabulary; knowledge about nature of emotion; emotional recognition); (f) Emotional responses while reading (immersion experiences, flow, peak experiences, emotional processes and states while reading).

\subsubsection{Reading and Social-Relational and Interpersonal Skills}

The relationship between reading and social-relational and interpersonal skills is investigated by 13 studies. Among these, seven focus on childhood and six on the school-age period (four are set in primary schools, one in a middle school, one in a high school). All articles underline a positive association between reading and the development of interpersonal skills since the early months of life and up to the end of high school. Focusing on early childhood, two relevant studies (Baker, 2013; Baker \& Rimm-Kaufman, 2014) and one longitudinal research (Ferretti \& Bub, 2017) reveal a significant and positive association between home literacy activities (e.g. shared book reading) provided by parents and children's development of socio-emotional skills (such as prosocial behaviors, engagement and focused involvement while interacting with others) and interpersonal skills (forming and maintaining friendships, comforting or helping other children, etc.). Still regarding the domestic environment, four studies analyze parents-child interactions during shared book readings and found that kids are exposed to a greater and more variable emotional and mental states talk while reading picture books with their parents then when playing with them (Drummond et al., 2014). Moreover, the more the parents and the child discuss about social-emotional issues, the more the child will tend to show prosocial and socially appropriate behaviors (Aram et al., 2017; Drummond et al., 2014; Schapira \& Aram, 2019), as shown also in the school-age period (Curtis, Zhou, \& Tao, 2020). The same association between reading and interpersonal skills development is reported in the nursery (Betawi, 2015). As far as the primary school is concerned, reading interventions are proven to foster prosocial behaviors and attitudes (Jones, Brown, \& Lawrence Aber, 2011), compliant and focused class behaviors (Brokamp et al., 2019), social awareness and metacognition (Venegas, 2019). With regards to middle school and high school, reading interventions promoted social-relational skills (Tijms, Stoop, \& Pollock, 2018) and sociability (Abdolrezapour \& Tavakoli, 2012). 
Table 1. Emotional constructs in Childhood

\begin{tabular}{|c|c|c|c|c|c|c|}
\hline Study & $\begin{array}{c}\text { Social - } \\
\text { interpersonal } \\
\text { skills }\end{array}$ & $\begin{array}{l}\text { Emotional - } \\
\text { behavioral } \\
\text { problems }{ }^{[2]}\end{array}$ & $\begin{array}{c}\text { Emotional and } \\
\text { behavioral } \\
\text { adaptive } \\
\text { competencies } \\
{[3]}\end{array}$ & $\begin{array}{l}\text { Understand - } \\
\text { sympathize } \\
\text { with others' } \\
\text { mind }{ }^{[4]}\end{array}$ & $\begin{array}{c}\text { Emotional } \\
\text { Knowledge }\end{array}$ & $\begin{array}{c}\text { Emotional } \\
\text { responses }{ }^{[6]}\end{array}$ \\
\hline $\begin{array}{l}\text { Drummond et al., } \\
2014\end{array}$ & $\mathrm{x}$ & & & & & \\
\hline Betawi, 2015 & $\mathrm{x}$ & $\mathrm{x}$ & $\mathrm{x}$ & & & \\
\hline Karniol, 2012 & & & & $\mathrm{x}$ & & \\
\hline Laforge et al., 2018 & & & & & $\mathrm{x}$ & \\
\hline $\begin{array}{c}\text { Grazzani \& Ornaghi, } \\
2011\end{array}$ & & & & $\mathrm{x}$ & $\mathrm{x}$ & \\
\hline Baker, 2013 & $\mathrm{x}$ & $\mathrm{x}$ & & & & \\
\hline $\begin{array}{c}\text { Schapira \& Aram, } \\
2019\end{array}$ & $\mathrm{x}$ & & & $\mathrm{x}$ & $\mathrm{x}$ & \\
\hline Ferretti \& Bub, 2017 & $\mathrm{x}$ & $\mathrm{x}$ & & & & \\
\hline $\begin{array}{c}\text { Baker \& } \\
\text { Rimm-Kaufman, } \\
2014\end{array}$ & $\mathrm{x}$ & $\mathrm{x}$ & $\mathrm{x}$ & & & \\
\hline Aram et al., 2017 & $\mathrm{x}$ & & & & & \\
\hline $\begin{array}{l}\text { Beazidou, et. al., } \\
2013\end{array}$ & & & & & $\mathrm{x}$ & \\
\hline $\begin{array}{l}\text { Riquelme \& Montero, } \\
2016\end{array}$ & & & $\mathrm{x}$ & $\mathrm{x}$ & $\mathrm{x}$ & \\
\hline Riquelme et al., 2013 & & & & $\mathrm{x}$ & $\mathrm{x}$ & \\
\hline
\end{tabular}

Description: [1] prosocial behavior, cooperation, assertiveness, adaptability, social awareness; [2] anxiety and depression, emotional maladjustment, social problems, conduct problems, aggressive behavior, ADHD symptoms; [3] self-control, emotional competence (expression and regulation), emotional stability, impulse-control, self-esteem; [4] empathy, theory of mind, understanding of emotions, social imagination, social understanding, sympathy, perspective-taking; [5] emotional vocabulary; knowledge about nature of emotion; emotional recognition; [6] immersion experiences, flow, peak experiences, emotional processes and states while reading.

\subsubsection{Reading and Emotional and Behavioral Problems}

The association between reading and the presence of emotional and behavioral problems is investigated by 8 articles: 4 studies are set in childhood, while the other four regard the school-age period (two in primary school, one in middle school, one in high school). As far as childhood is concerned, two studies with large samples (Baker, 2013; Baker \& Rimm-Kaufman, 2014) and one longitudinal research (Ferretti \& Bub, 2017) underline that home literacy interactions (e.g. shared book reading) and the presence of a large number of books at home have a negative and significant correlation with children's externalizing behaviors, conduct problems, negativity, and hyperactivity and impulsivity while interacting with others. Similarly, this result appears also in a nursery after a reading intervention (Betawi, 2015). As regards to school-age, poor readers in primary school result to feel more anger, sadness, and anxiety and perceive to be more unpopular than stronger readers (Morgan et al., 2012), while having reading difficulties at middle school predicts anxiety and depression, social problems, and aggressive and delinquent behaviors (Undheim et al., 2011). On the other hand, a two year reading program in schools reduces hostile attribution, depressive and ADHD symptoms and, after two years, aggressive behavior (Jones et al., 2011). Another five weeks reading intervention on high school hyperactive students brought a significant decrease in hyperactivity. However, this gain was not maintained after two weeks by the end of the treatment (Pang \& Zhang, 2011). 


\subsubsection{Reading and Emotional and Behavioral Adaptive Competencies}

Ten articles examine the relation between reading and emotional and behavioral competencies. Among them, three are focused on childhood and seven on the school-age period (five are set in primary school, one in middle school, one in high school). These studies underline how reading predicts a better emotional well-being and stability from the first months of life to the end of high school. The childhood studies show that domestic literacy activities foster self-control (controlling temper, accepting peer ideas for group activities, etc.) (Baker \& Rimm-Kaufman, 2014). Reading interventions appear to bring to similar results in nursery (Betawi, 2015), while mediated reading programs are associated with better emotional regulation in the transition from kindergarten to primary school (Riquelme \& Montero, 2013, 2016). Still regarding primary school, reading classes appear to improve self-confidence (Casserly, 2011; Venegas, 2019) and emotional stability (Brokamp et al., 2019); literacy interventions support emotional regulation (Jones et al., 2011); bibliotherapeutic book clubs foster emotional expression and self-confidence in middle school (Tijms et al., 2018), while one reading training with books with high emotional contents leads to better emotional intelligence in high school (Abdolrezapour \& Tavakoli, 2012).

Table 2. Emotional constructs in School-Age

\begin{tabular}{|c|c|c|c|c|c|c|}
\hline Study & $\begin{array}{c}\text { Social - } \\
\text { interpersonal } \\
\text { skills }^{[1]}\end{array}$ & $\begin{array}{c}\text { Emotional - } \\
\text { behavioral } \\
\text { problems }\end{array}$ & $\begin{array}{c}\text { Emotional and } \\
\text { behavioral } \\
\text { adaptive } \\
\text { competencies } \\
{[3]}\end{array}$ & $\begin{array}{l}\text { Understand - } \\
\text { sympathize } \\
\text { with others' } \\
\text { mind }{ }^{[4]}\end{array}$ & $\begin{array}{c}\text { Emotional } \\
\text { Knowledge }\end{array}$ & $\begin{array}{c}\text { Emotional } \\
\text { responses }{ }^{[6]}\end{array}$ \\
\hline $\begin{array}{c}\text { Riquelme \& Montero, } \\
2013\end{array}$ & & & $\mathrm{x}$ & $\mathrm{x}$ & $\mathrm{x}$ & \\
\hline Casserly, 2011 & & & $\mathrm{x}$ & & & \\
\hline Angantyr et al., 2016 & & & & $\mathrm{x}$ & & \\
\hline Ornaghi et al., 2014 & & & & $\mathrm{x}$ & $\mathrm{x}$ & \\
\hline Curtis et al., 2020 & $\mathrm{x}$ & & & $\mathrm{x}$ & & \\
\hline $\begin{array}{l}\text { Lysaker \& Tonge, } \\
2013\end{array}$ & & & & $\mathrm{x}$ & $\mathrm{x}$ & \\
\hline Jones et al., 2011 & $\mathrm{x}$ & $\mathrm{x}$ & $\mathrm{x}$ & & & \\
\hline Brokamp et al., 2019 & $\mathrm{x}$ & & $\mathrm{x}$ & & & \\
\hline Gordon, 2017 & & & & $\mathrm{x}$ & $\mathrm{x}$ & \\
\hline Morgan et al., 2012 & & $\mathrm{x}$ & & & & \\
\hline Beck et.al, 2012 & & & & $\mathrm{x}$ & $\mathrm{x}$ & \\
\hline $\begin{array}{l}\text { Kumschick et al., } \\
2014\end{array}$ & & & & $\mathrm{x}$ & $\mathrm{x}$ & \\
\hline Venegas, 2019 & $\mathrm{x}$ & & $\mathrm{x}$ & $\mathrm{x}$ & & \\
\hline $\begin{array}{c}\text { Tomé-Fernández et } \\
\text { al., } 2019\end{array}$ & & & & $\mathrm{x}$ & & \\
\hline Stutler, 2011 & & & & $\mathrm{x}$ & & $\mathrm{x}$ \\
\hline Undheim et al., 2011 & & $\mathrm{x}$ & & & & \\
\hline Chisholm et al., 2017 & & & & $\mathrm{x}$ & & \\
\hline Tijms et al., 2018 & $\mathrm{x}$ & & $\mathrm{x}$ & & & \\
\hline Dylman et al., 2020 & & & & & $\mathrm{x}$ & \\
\hline Yussof et al., 2013 & & & & & & $\mathrm{x}$ \\
\hline $\begin{array}{c}\text { Boatright \& Allman, } \\
2018\end{array}$ & & & & $\mathrm{x}$ & & \\
\hline Pang \& Zhang, 2011 & & $\mathrm{x}$ & & & & \\
\hline $\begin{array}{l}\text { Abdolrezapour \& } \\
\text { Tavakoli, } 2012\end{array}$ & $\mathrm{x}$ & & $\mathrm{x}$ & $\mathrm{x}$ & & \\
\hline Gerrig et al., 2016 & & & & $\mathrm{x}$ & & $\mathrm{x}$ \\
\hline
\end{tabular}

Description: [1] prosocial behavior, cooperation, assertiveness, adaptability, social awareness; [2] anxiety and depression, emotional maladjustment, social problems, conduct problems, aggressive behavior, ADHD symptoms; [3] self-control, emotional competence (expression and regulation), emotional stability, impulse-control, self-esteem; [4] empathy, theory of mind, understanding of emotions, social imagination, social understanding, sympathy, 
perspective-taking; [5] emotional vocabulary; knowledge about nature of emotion; emotional recognition; [6] immersion experiences, flow, peak experiences, emotional processes and states while reading.

\subsubsection{Reading and the Ability to Understand and Sympathize With Others' Mind}

With 30 studies focused on it, the ability to understand and sympathize with others' mind is the most represented emotional construct in our review: five articles are focused on childhood, 15 on the school-age period (ten are set in primary school, two in middle school, three in high school), and 10 on adulthood. One of these studies covers the highest age period of our review: 17-73 years old (Koopman, 2016). The childhood studies reveal that story-book and reading training evoke theory of mind and empathic understanding in self, others, and even animals (Grazzani \& Ornaghi, 2011; Karniol, 2012). Socio-emotional utterances generated during shared-book reading interactions are associated as well with empathy growth both in childhood (Schapira \& Aram, 2019) and in school-age period (Curtis et al., 2020). Mediated reading fosters empathy even in the transition from preschool to school and in primary school (Riquelme \& Montero, 2013, 2016; Riquelme et al., 2013). Children's literacy assessed in primary school relates to the ability to understand others' emotions (Kumschick et al., 2014). Reading programs based on socio-emotional texts seem to reduce sex differences in empathy expression (Angantyr et al., 2016), while literature circles, reading interventions and reading classes based on multicultural literature were found to increase empathy and theory of mind in primary school (Beck et al., 2012; Gordon, 2017; Kumschick et al., 2014; Lysaker \& Tonge, 2013; Tomé-Fernández et al., 2019; Venegas, 2019), with stable effects even after six months by the end of the intervention (Ornaghi, Brockmeier, \& Grazzani, 2014). Similar results were found in middle school (Stutler, 2011), while the use of graphic novels elicited empathy and historical empathy (Chisholm et al., 2017). As about high school, literature circles (Boatright \& Allman, 2018) and reading training with social-emotional content books (Abdolrezapour \& Tavakoli, 2011) promote empathy. Laboratory studies with adolescents and university students underline that engaging (Gerrig et al., 2016) and foregrounding texts (Koopman, 2016), as well as books with negative contents (Altmann et al., 2012), can foster empathy. As about adulthood, a study with university students underlines that women read more than men and show a stronger association between reading appreciation and empathy; instead, reading non-fiction (such as university textbooks) does not associate with empathic scorings (McCreary \& Marchant, 2017). Similarly, textual difficulty is negatively associated with empathy (Junker \& Jacquemin, 2017). On the other side, fiction reading significantly relates to theory of mind abilities (Tabullo et al., 2018). A series of qualitative studies on university students and pre-service teachers reveals that reading classes and bibliotherapeutic sessions promote empathic reflections and connections (Chamberlain, 2019; Hoggan \& Cranton, 2015), empathic understandings of issues such as suicide and bullying (Pytash, 2013), and perspective taking and reflections about racism, reducing prejudice and stereotypes (Glenn, 2012; Slay \& Morton, 2020). Only two studies do not find a significant increase in empathy over the course, respectively, of a 15 weeks reading workshop (Junker \& Jacquemin, 2017) and a four week class reading intervention (Gordon, 2017).

\subsubsection{Reading and Emotional Knowledge}

The association between reading and emotional knowledge is examined by 13 studies: six refer to childhood and seven to school-age (six are set in primary school, one covers the last year of middle school and the high school). These studies investigate the emotional knowledge: with this term we refer to the knowledge about the emotions' nature, the emotional vocabulary and ability to recognize the emotional facial expressions and to label them with the right term. Except for two studies (Gordon, 2017; Laforge et al., 2018), all of these articles reveal that reading has a positive association with emotional knowledge: the more one reads, the more he/she will become an 'expert' of emotions. This result is extended to all the ages considered in these studies. More specifically, reading practice has a significant impact on the recognition of emotions and this evidence is found both in preschool (Riquelme \& Montero, 2016; Riquelme et al., 2013) and primary school (Beck et al., 2012; Lysaker \& Tonge, 2013; Riquelme \& Montero, 2013). The research group of Riquelme and Montero (2013, 2016) and Riquelme and colleagues (2013) used the same tools to assess this emotional component. The same effect is also found in the emotions comprehension in preschool (Grazzani \& Ornaghi, 2011) and primary school (Beck et al., 2012; Kumschick et al., 2014; Lysaker \& Tonge, 2013), with a stable effect in follow-up (Ornaghi et al., 2014). Emotional vocabulary is also increasing as a result of reading practice (Dylman et al., 2020; Kumschick et al., 2014; Ornaghi et al., 2014). Parents' socio-emotional discourses evaluated in conversations during and after reading in the family have an impact on children's understanding of the causes of emotions (Schapira \& Aram, 2019). The study by Beazidou and colleagues (2013) highlights the techniques used by teachers to foster emotional knowledge during reading in preschool: they use movements and voice as mediators of emotional understanding and expression, urge pupils to find the cause of an emotion, compare the feelings of different characters and lead to imagine what will happen next. 
Table 3. Emotional constructs in Adulthood

\begin{tabular}{|c|c|c|c|c|c|c|}
\hline Study & $\begin{array}{c}\text { Social - } \\
\text { interpersonal } \\
\text { skills }{ }^{[1]}\end{array}$ & $\begin{array}{l}\text { Emotional - } \\
\text { behavioral } \\
\text { problems }\end{array}$ & $\begin{array}{c}\text { Emotional and } \\
\text { behavioral } \\
\text { adaptive } \\
\text { competencies } \\
\text { [3] }\end{array}$ & $\begin{array}{l}\text { Understand - } \\
\text { sympathize } \\
\text { with others' } \\
\text { mind }{ }^{[4]}\end{array}$ & $\begin{array}{c}\text { Emotional } \\
\text { Knowledge }\end{array}$ & $\begin{array}{c}\text { Emotional } \\
\text { responses }\end{array}$ \\
\hline $\begin{array}{c}\text { McCreary \& } \\
\text { Marchant, } 2017\end{array}$ & & & & $\mathrm{x}$ & & \\
\hline Pytash, 2013 & & & & $\mathrm{x}$ & & \\
\hline $\begin{array}{c}\text { Hoggan \& Cranton, } \\
2015\end{array}$ & & & & $\mathrm{x}$ & & \\
\hline Hartung et al., 2016 & & & & & & $\mathrm{x}$ \\
\hline Hsu et al., 2014 & & & & & & $\mathrm{x}$ \\
\hline Iacozza et al., 2017 & & & & & & $\mathrm{x}$ \\
\hline Altmann et al., 2012 & & & & $\mathrm{x}$ & & $\mathrm{x}$ \\
\hline Tabullo et al., 2018 & & & & $\mathrm{x}$ & & \\
\hline Koopman, 2015 & & & & $\mathrm{x}$ & & $\mathrm{x}$ \\
\hline $\begin{array}{l}\text { Junker \& Jacquemin, } \\
\qquad 2017\end{array}$ & & & & $\mathrm{x}$ & & \\
\hline Slay \& Morton, 2020 & & & & $\mathrm{x}$ & & \\
\hline Glenn, 2012 & & & & $\mathrm{x}$ & & \\
\hline Chamberlain, 2018 & & & & $\mathrm{x}$ & & \\
\hline
\end{tabular}

Description: [1] prosocial behavior, cooperation, assertiveness, adaptability, social awareness; [2] anxiety and depression, emotional maladjustment, social problems, conduct problems, aggressive behavior, ADHD symptoms; [3] self-control, emotional competence (expression and regulation), emotional stability, impulse-control, self-esteem; [4] empathy, theory of mind, understanding of emotions, social imagination, social understanding, sympathy, perspective-taking; [5] emotional vocabulary; knowledge about nature of emotion; emotional recognition; [6] immersion experiences, flow, peak experiences, emotional processes and states while reading.

\subsubsection{Reading and Emotional Responses While Reading}

The emotional responses elicited by reading is examined in 8 articles: 3 refer to school-age (1 is related to middle school and 2 to high school) and 5 to adulthood. Some of these articles (Stutler, 2011; Yussof, Jamian, Hamzah, \& Roslan, 2013) underline that reading programs can evoke states of flow (a state of enjoyment in which sensations are heightened and thoughts and feelings fade, with a loss of time, place and self; Csikszentmihalyi, 1990), peak experiences (states of pure joy associated with moments of great truth or beauty, with a lack of awareness about time, space and self) and emotional responses. Foregrounding and engaging books, with first person pronouns and fear-inducing passages generate amusement, emotional responses and immersion experiences (Gerrig et al., 2016; Hartung, Burke, Hagoort, \& Willems, 2016; Hsu, Conrad, \& Jacobs, 2014; Koopman, 2016). Native language books (Iacozza et al., 2017) elicit stronger emotional reactions than foreign language books. Texts with negative contents evoke stronger emotional reactions and neural responses in comparison to neutral texts (Altmann et al., 2012; Hsu et al., 2014).

\section{Discussion}

In line with educational and psychological literature (Adrián et al., 2005, Mar et al., 2006) most of our findings underline an association between reading and socio-emotional skills. Indeed, only three studies of our sample (Gordon, 2017; Junker \& Jacquemin, 2017; Laforge et al., 2018) do not highlight a significant association between reading and students' emotional scoring. These studies are conducted in naturalistic settings (daycare centers, a primary school and a university) with small samples and promote short term interventions (respectively, 3, 15 and 4 weeks) that foster empathic responses and emotional comprehension, but do not produce significant enhancements over time. Moreover, one of these studies does not find an effect over emotional vocabulary. However, these results may be due, as suggested 
by the authors, to the limited amount of time (that, unlike laboratories studies, may not have been enough in naturalistic settings) and to the use of qualitative and holistic measures (instead of the tools used in lab settings). Indeed, children's development of emotion comprehension may require longer time, as suggested by Pons and Harris (2000).

Besides these exceptions, the articles included in our review show a positive effect of reading on emotional dimensions all across several developmental stages. In fact, they cover a life span from the early months of life to adulthood, involving samples composed by infants, as well as school-age participants and adults. In contrast to the findings of Kozak and Recchia (2019), most of our articles (especially those with an educational perspective) focus on the school-age period, adding information on this still little studied evolutionary phase. Interestingly, adulthood samples are mostly composed by university students, while we found no study specifically focused on elderly or middle-aged samples. Thus, our review sheds light on a gap in the scientific literature and highlights the need of research investigating the relationship between reading and emotional dimensions even in other life stages with older participants.

Our review shows a beneficial effect related to books starting from childhood. The more a child is exposed to shared book readings, the more he/she will develop interpersonal and empathic skills and theory of mind abilities and will count on better emotional well-being and competence. Even more important, the more a child is provided with reading experiences, the less he/she will be likely to develop behavioral problems (e.g. externalizing behaviors, conduct problems, negativity towards parents). These associations are clear both in educational and family settings and are supported, in particular, by three studies (derived from the USA survey: Early Childhood Longitudinal Study, Birth and Kindergarten Cohort) that were based on very numerous samples and on quantitative and/or longitudinal research design (Baker, 2013; Baker \& Rimm-Kaufman, 2014; Ferretti \& Bub, 2017).

A possible way to portray these findings is suggested by a sample of 4 articles that, in both childhood and school-age participants, investigate the interactive processes elicited by shared book readings. Indeed, these studies show that reading interactions evoke more emotional utterances and mental states talk by both parents and children in comparison to other playing activities. Among these studies the longitudinal correlational research conducted by Curtis and colleagues (2020) must be highlighted, since its methodological reliability. Results show that parents' emotional talk during shared book reading was related to children's higher effortful control, that, in turn, was positively associated with children's higher sympathy and more socially appropriate behaviors. These findings are in line with the literature (Howe, Rinaldi, \& Recchia, 2010), that demonstrates how this kind of interaction can foster children's better socio-emotional skills.

Similar results have been found in the school-age period and in adulthood. Scholastic settings are mostly taken into consideration and both quantitative and qualitative studies reveal that reading interventions (class readings, bibliotherapeutic interventions, reading aloud or silently, reading programs, literature circles, book clubs) and good reading habits support the development of relational abilities, emotional competence and empathic skills. Moreover, in both childhood and school-age period, there is evidence that these activities and being a strong reader enhance emotional knowledge, meaning the competence in recognizing and correctly labeling emotions and the awareness about their nature and causes. In particular two quantitative controlled studies (Grazzani \& Ornaghi, 2011; Ornaghi et al., 2014) show that a 2 month reading training, based on emotional contents and followed by activities focused on emotional knowledge, promotes both empathy and emotion comprehension, with a stable effect over 6 months (Ornaghi et al., 2014).

One of a teachers' most implemented strategies is the use of multicultural literature, counter-narratives, or books with high socio-emotional contents to enhance empathy and reduce prejudice and intercultural conflicts. Even the use of historical graphic novels (Chisholm et al., 2017) has been effective.

Importantly, the environment is shown to have an influence over the association between reading experiences and emotional development, since educators and teachers can play an important role in fostering this positive relation. Three methodologically accurate studies (Riquelme \& Montero, 2013, 2016; Riquelme et al., 2013), conducted with a quantitative research design in naturalistic settings (in the transition from kindergarten to primary school), implemented a training based on mediated reading. Results, supported by comparisons with control groups, show that this practice fosters interactions between the reader and the group and promotes the development of theory of mind. Other studies suggest that also other kinds of interactions, such as group discussions among peers with or without an adult facilitator (with secondary school and university students), support the building of connections between the text and the readers' lives and foster reflection and awareness about one's emotions and empathic feelings. Moreover, teachers, through a supportive attitude and by providing good reading models, can improve students' school behaviors and emotional well-being and, indirectly, support their literacy skills (Brokamp et al., 2019).

This positive influence of reading over behavioral and emotional problems is underlined also by two articles (Morgan et 
al., 2012; Undheim et al., 2011) (one in primary and one in middle school), that show that being a poor reader and having reading difficulties correlate with the presence of anxiety, depression, social problems and aggressive behaviors. However, reading interventions have proven to be effective in reducing these manifestations. This result may depend on the finding that good readers also rely on better emotional regulation and expression that, in turn, may improve impulse control and foster psychological protective factors such as social success and greater self-esteem. Since a five week intervention addressing hyperactivity in high school students showed only a short-term efficacy (Pang \& Zhang, 2011), long-lasting reading interventions should be implemented in order to obtain more stable behavioral benefits. Indeed, a reading intervention performed by Jones and colleagues (2011) showed a decrease in hostile attributions after one year, and a steeper decline of ADHD and depression symptoms over two years; however improvements in aggressive interpersonal negotiation strategies and social competencies were found only after two years. In line with the developmental cascades theory (Masten \& Cicchetti, 2010), this may depend on the fact that interventions have to change, firstly, social cognitions and social-emotional dimensions in order to achieve subsequent changes in behaviors. As suggested by this theory, these psychological and behavioral gains would lead to long-term effects, thwarting the onset of later delinquent behaviors and providing universal benefits in academic skills (Pang \& Zang, 2011; Jones et al., 2011) and in other developmental domains (delayed onset of substance use and reduced academic disengagement/failure) (Eddy et al., 2003; Lochman \& Wells, 2004).

This association between reading and emotional dimensions may be explained by the emotional responses elicited by reading. Reading fiction and narrative stories (Altmann et al., 2012; Hsu et al., 2014) activates neural areas related to theory of mind cognitive (dorsomedial prefrontal cortex, bilateral temporal poles and left posterior superior temporal sulcus) and emotional dimensions (left inferior frontal gyrus, mid-cingulate cortex). These articles analyze the connections between reading and emotions from a neuroscientific point of view, emphasizing the role of reading in activating neural processes linked to empathy. Other studies in lab settings underline that texts with socio-emotional contents, connotative language and with engaging features evoke strong emotional responses. In line with the literature (Oatley, 1999), first person narratives also promote a deeper immersion experience and emotional reactions.

Several studies also suggest that it is not the reading per se that promotes empathy and emotional growth: textual characteristics are important (Junker \& Jacquemin, 2017). As shown by previous research (Batini et al., 2018; Kidd \& Castano, 2013, 2017), fiction, unlike non-fiction texts, have resulted to foster empathy and theory of mind (Hoggan \& Cranton, 2015; McCreary \& Marchant, 2017; Tabullo et al., 2018). Reading fiction may elicit deep emotional reactions and empathic connections, promote awareness and psychological growth and foster transformative learning and critical thinking about the self and the world.

Another important finding is that the positive relationship between reading and emotional development is valid regardless of gender. This result is in contrast with previous studies that found a stronger association in females (Mar et al., 2009). In fact, only two studies identify a clear and significant gender difference in empathic scoring after reading: one in favour of male participants (Tabullo et al., 2018), and one in favour of females (McCreary \& Marchant, 2017). Interestingly, one of our studies suggests that reading may reduce sexual difference in empathic manifestations by improving males' emotional skills (Angantyr et al., 2016).

In conclusion, our review highlights a positive association between reading and socio-emotional dimensions across several developmental stages and regardless of gender and setting, supporting the idea of a lifelong reading. Moreover, this association is underlined through different assessment tools in both qualitative (e.g. Tomé-Fernández et al., 2019) and quantitative studies (e.g. Riquelme \& Montero, 2013), as well as in studies without (e.g. Baker, 2013) or with the promotion of an intervention, such as training (e.g. Ornaghi et al., 2014), workshops (e.g. Slay \& Morton, 2020) or reading sessions (e.g. Curtis et al., 2020).

However, caution is necessary in interpreting these results, since most of our findings show bidirectional associations, not proving causal effects, meaning that more studies are needed to clarify this relationship. Despite this, the positive effects that reading interventions seem to have in reducing psychological symptomatology and enhancing empathy, as well as their activation of brain areas related to theory of mind, supports the implementation of reading programs in family and educational settings at every evolutionary stage in order to achieve better socio-emotional skills.

\subsection{Limitations}

Although this review offers a deeper perspective with regard to the analysis of the association between reading and emotions, we acknowledge that it is possible to identify two main categories of limitations. The first concerns the inclusion criteria. Generally speaking, we maintained a global focus of research and this choice could be seen as a strength, because it led us to collect a huge set of articles on which we developed some interesting comparisons. On the other hand, we had to deal with comparing studies with different focuses. For example, we pointed out that all empirical studies were included (see the second criterion), independently from research designs. Consequently, all studies have a 
different setting (e.g. home environments, labs, schools, universities or other services with an explicit educational purpose) and we did not make a discrimination in this way (see the fifth criterion). Still, studies investigated the reading component in a broad sense (see the sixth criterion). In some cases, studies (e.g. Aram et al., 2016; Drummond et al., 2014; Lysaker \& Tonge, 2013) focused on a shared reading modality; in others (e.g. Boatright \& Allman, 2018; Chisholm et al., 2017; LaForge et al., 2018) they concerned an individual reading modality; in others, reading habits and general language skills were assessed and therefore it was not implemented any intervention (e.g. Baker, 2013; Baker \& Rimm-Kaufman, 2014). Thus, it was not possible to make a unitary comparison and grasp specific mechanisms of reading that were more associated with the emotional constructs investigated. In any case, this open-minded approach led us to collect some noteworthy empirical evidence, even for future research and educational implications.

The second type of limitations relates to the data collection process. Since we reported the complexity to consider a shared, unique definition of socio-emotional competence, we used several keywords (see Search strategy) in order to account for the complexity and multidimensionality of the emotional constructs and prevent studies with different constructs - but inherent to our research focus - from being excluded. As a matter of fact, we analyzed a huge number of articles that focused on the same emotional constructs, but also on socio-emotional competencies with different or more hues of meaning. This, although has provided a great deal of data, has often led us to compare different constructs, or similar constructs but defined in different terms in individual studies.

\section{Conclusion and Future Directions}

We are aware that the analytical work carried out can not be considered exhaustive. Despite the limitations of this review and the complexity inherent in the variables of reading and emotions that are the subject of this research, we consider the path of this analysis and the results found very meaningful to better understand the association between reading and emotions. Our broad investigation may inspire more specific foci of research: for example, the categorization we have carried out on the broad construct of socio-emotional competence, subdividing the studies into six main areas, could provide a starting point for future reviews focusing on more particular aspects; the same mechanism could also be carried out for the reading components, developing surveys aimed at evaluating interventions based on a specific type of reading, such as mediated reading. Moreover, as shown, the effects of interactive reading (Lysaker \& Tonge, 2013; Riquelme \& Montero, 2016) are proven to improve socio-emotional competence; so it may be interesting to argue about the implications that the continuative implementation of this practice in the schools may have over long-term periods. Finally, as discussed before, the impact of reading on adult and elderly populations emotions may be a particular matter of interest when formulating new research may be a particular matter of interest, since we have collected only one study which takes into account older participants (Koopman, 2015), even though we did not set a restriction about this criterion.

\section{Acknowledgements}

This work is carried out as part of the research project "Leggere: Forte!" ("Reading: So Cool!"), funded by the "Regione Toscana", Italy. "Leggere: Forte!" is an educational policy of the "Regione Toscana" that aims to insert the daily reading aloud of the teachers for their pupils in the whole Tuscan education and training system, from 0 to 19 years. The research activity serves as support and guidance for the educational policy. "Leggere: Forte!" is led with the partnership and scientific coordination of the University of Perugia (scientific director: Prof. Federico Batini) and the partnership of the Regional School Office of Tuscany (depending by the Ministry of Education, University and Research), Cepell ("Centro per il libro e la lettura" - "Centre for Book and Reading" of the Ministry of National Heritage and Culture), Indire ("Istituto Nazionale di Documentazione Innovazione e Ricerca Educativa" - "National Institute of Documentation, Innovation and Educational Research") and the collaboration of LaAV (a movement of reading aloud volunteers led by Associazione Nausika). Thanks to the colleagues of the research group Irene Scierri, Martina Marsano and Kris Martin for the support in the various drafts of this paper.

\section{References}

Abdolrezapour, P., \& Tavakoli, M. (2012). The relationship between emotional intelligence and EFL learners' achievement in reading comprehension. Innovation in Language Learning and Teaching, 6, 1-13. https://doi.org/10.1080/17501229.2010.550686

Abu-Shihab, I. (2011). Reading as critical thinking. Asian Social Science, 7, 209-218. https://doi.org/10.5539/ass.v7n8p209

Adrián, J. E., Clemente, R. A., Villanueva, L., \& Rieffe, C. (2005). Parent-child picture-book reading, mothers' mental state language and children's theory of mind. Journal of Child Language, 32, 673-686. https://doi.org/10.1017/S0305000905006963 
Albanese, O., \& Molina, P. F. M. (2008). Lo sviluppo della comprensione delle emozioni e la sua valutazione. La versione italiana del Test di Comprensione delle Emozioni (TEC). Milano: Unicopli.

Altmann, U., Bohrn, I. C., Lubrich, O., Menninghaus, W., \& Jacobs, A. M. (2012). The power of emotional valence-from cognitive to affective processes in reading. Frontiers in human neuroscience, 6, 192. https://doi.org/10.3389/fnhum.2012.00192

Angantyr, M., Hansen, E. M., Eklund, J. H., \& Malm, K. (2016). Reducing sex differences in children's empathy for animals through a training intervention. Journal of Research in Childhood Education, 30, 273-281. https://doi.org/10.1080/02568543.2016.1178198

Appel, M., Koch, E., Schreier, M., and Groeben, N. (2002). Aspekte des leseerlebens: skalenentwicklung [experiential states during reading: scale development]. Zeitschrift für Medienpsychol. 14, 149-154. https://doi.org/10.1026//1617-6383.14.4.149

Aram, D., Deitcher, D. B., Shoshan, T. S., \& Ziv, M. (2017). Shared book reading interactions within families from low socioeconomic backgrounds and children's social understanding and prosocial behavior. Journal of Cognitive Education and Psychology, 16, 157-177. https://doi.org/10.1891/1945-8959.16.2.157

Ayotte, V., Saucier, J. F., Bowen, F., Laurendeau, M. C., Fournier, M. \& Blais, J. G. (2003). Teaching multiethnic urban adolescents how to enhance their competencies: Effects of a middle school primary prevention program on adaptation. Journal of Primary Education, 24(1), 7-23. https://doi.org/10.1023/A:1025071516447

Baker, C. E. (2013). Fathers' and mothers' home literacy involvement and children's cognitive and social emotional development: Implications for family literacy programs. Applied Developmental Science, 17, 184-197. https://doi.org/10.1080/10888691.2013.836034

Baker, C. E., \& Rimm-Kaufman, S. E. (2014). How homes influence schools: Early parenting predicts African American children's classroom social-emotional functioning. Psychology in the Schools, 51, 722-735. https://doi.org/10.1002/pits.21781

Bar-On, R. (2006). The Bar-On model of emotional-social intelligence (ESI). Psicothema, 18, 13-25.

Baron-Cohen, S., \& Wheelwright, S. (2004). The empathy quotient: An investigation of adults with Asperger syndrome or high functioning autism, and normal sex differences. Journal of Autism \& Developmental Disorders, 34, 163-175. https://doi.org/10.1023/B:JADD.0000022607.19833.00

Baron-Cohen, S., O'riordan, M., Stone, V., Jones, R., \& Plaisted, K. (1999). Recognition of faux pas by normally developing children and children with Asperger syndrome or high-functioning autism. Journal of autism and developmental disorders, 29(5), 407-418. https://doi.org/10.1023/A:1023035012436

Baron-Cohen, S., Wheelwright, S., Hill, J., Raste, Y., \& Plumb, I. (2001). The "Reading the Mind in the Eyes" Test revised version: A study with normal adults, and adults with Asperger Syndrome or high-functioning autism. Journal of Child Psychology and Psychiatry, 42, 241-251. https://doi.org/10.1017/S0021963001006643

Barquero, L. A., Davis, N., \& Cutting, E. (2014). Neuroimaging of reading intervention: A systematic review and activation likelihood estimate meta-analysis. Plos One, 9. https://doi.org/10.1371/journal.pone.0083668

Barrett, T. C., \& Smith, R. (1974). Teaching reading in the middle grades. Boston, MA: Addison Wesley Publishing Company.

Batini, F., Bartolucci, M., \& Timpone, A. (2018). The effects of reading aloud in the primary school. Psychology and Education, 55(1\&2), 111-122.

Beazidou, E., Botsoglou, K., \& Vlachou, M. (2013). Promoting emotional knowledge: strategies that Greek preschool teachers employ during book reading. Early Child Development and Care, 183, 613-626. https://doi.org/10.1080/03004430.2012.678490

Beck, L., Kumschick, I. R., Eid, M., \& Klann-Delius, G. (2012). Relationship between language competence and emotional competence in middle childhood. Emotion, 12, 503. https://doi.org/10.1037/a0026320

Betawi, I. A. (2015). What effect does story time have on toddlers' social and emotional skills. Early Child Development and Care, 185, 594-600. https://doi.org/10.1080/03004430.2014.943756

Boatright, M. D., \& Allman, A. (2018). Last Year's Choice Is This Year's Voice: Valuing Democratic Practices in the Classroom through Student-Selected Literature. Democracy and Education, 26, 2.

Boelen, P. A., den Bout, J. V., De Keijser, J. O. S., \& Hoijtink, H. (2003). Reliability and validity of the Dutch version of the Inventory of Traumatic Grief (ITG). Death studies, 27, 227-247. https://doi.org/10.1080/07481180302889 
Bonino, S., Coco, A. L., \& Tani, F. (1998). Empatia: i processi di condivisione delle emozioni. Firenze: Giunti.

Brokamp, S. K., Houtveen, A. A., \& van de Grift, W. J. (2019). The relationship among students' reading performance, their classroom behavior, and teacher skills. The Journal of Educational Research, 112, 1-11. https://doi.org/10.1080/00220671.2017.1411878

Bus, A. G., Takacs, Z. K., \& Kegel, C. A. (2015). Affordances and limitations of electronic storybooks for young children's emergent literacy. Developmental Review, 35, 79-97. https://doi.org/10.1016/j.dr.2014.12.004

Busselle, R., \& Bilandzic, H. (2009). Measuring narrative engagement. Media Psychology, 12, 321-347. https://doi.org/10.1080/15213260903287259

Caldwell, B. M., \& Bradley, R. H. (1984). Home observation for measurement of the environment. Little Rock: University of Arkansas at Little Rock.

Carpendale, J. I. M., \& Lewis, C. (2006). How children develop social understanding. Malden, MA: Blackwell.

Casserly, A. M. (2011). Children's experiences of reading classes and reading schools in Ireland. Support for Learning, 26, 17-24. https://doi.org/10.1111/j.1467-9604.2010.01475.x

Chamberlain, D. (2019). The experience of older adults who participate in a bibliotherapy/poetry group in an older adult inpatient mental health assessment and treatment ward. Journal of Poetry Therapy, 32, 223-239. https://doi.org/10.1080/08893675.2019.1639879

Chisholm, J. S., Shelton, A. L., \& Sheffield, C. C. (2017). Mediating emotive empathy with informational text: Three students' think-aloud protocols of Gettysburg: The Graphic Novel. Journal of Adolescent \& Adult Literacy, 61, 289-298. https://doi.org/10.1002/jaal.682

Conduct Problems Prevention Research Group (1999). Initial impact of the Fast Track prevention trial for conduct problems: I. The high-risk sample. Journal of consulting and clinical psychology, 67(5), 631. https://doi.org/10.1037/0022-006X.67.5.631

Csikszentmihalyi, M. (1990). Flow: The psychology of optimal experience. New York, NY: HarperCollins.

Curtis, K., Zhou, Q., \& Tao, A. (2020). Emotion talk in Chinese American immigrant families and longitudinal links to children's socioemotional competence. Developmental Psychology, 56, 475. https://doi.org/10.1037/dev0000806

Dadds, M. R., Hunter, K., Hawes, D. J., Frost, A. D., Vassallo, S., Bunn, P., ... \& El Masry, Y. (2008). A measure of cognitive and affective empathy in children using parent ratings. Child psychiatry and human development, 39(2), 111-122. https://doi.org/10.1007/s10578-007-0075-4

Dalhberg, L. L., Toal, S. B., \& Behrens, C. B. (1998). Measuring violence-related attitudes, beliefs, and behaviors among youths: A compendium of assessment tools. Centers for Disease Control and Prevention, National Center for Injury Prevention and Control, Atlanta, GA.

Davis, M. H. (1983). Measuring individual differences in empathy: Evidence for a multidimensional approach. Journal of Personality and Social Psychology, 44(1), 113-126. https://doi.org/10.1037/0022-3514.44.1.113

Djikic, M., Oatley, K., \& Moldoveanu, M. C. (2009). Reading other minds: Effects of literature on empathy. Scientific Study Of Literature, 3, 28-47. https://doi.org/10.1075/ssol.3.1.06dji

Dodell-Feder, D., \& Tamir, D. I. (2018). Fiction reading has a small positive impact on social cognition: A meta-analysis. Journal of Experimental Psychology: General, 147(11), 1713. https://doi.org/10.1037/xge0000395

Dore, R. A., Hassinger-Das, B., Brezack, N., Valladares, T. L., Paller, A., Vu, L., Michnick Golinkoff, R., \& Hirsh-Pasek, K. (2018). The parent advantage in fostering children's e-book comprehension. Early Child. Res. Q., 44, 24-33. https://doi.org/10.1016/j.ecresq.2018.02.002

Drummond, J., Paul, E. F., Waugh, W. E., Hammond, S. I., \& Brownell, C. A. (2014). Here, there and everywhere: emotion and mental state talk in different social contexts predicts empathic helping in toddlers. Frontiers in psychology, 5, 361. https://doi.org/10.3389/fpsyg.2014.00361

Dunn, L. M., \& Dunn, D. M. (2004). Peabody picture vocabulary test (PPVT) (deutsche Version). Göttingen, Hogrefe.

Dylman, A. S., Blomqvist, E., \& Champoux-Larsson, M. F. (2020). Reading habits and emotional vocabulary in adolescents. Educational Psychology, 1-14. https://doi.org/10.1080/01443410.2020.1732874

Eddy, J. M., Reid, J. B., Stoolmiller, M., \& Fetrow, R. A. (2003). Outcomes during middle school for an elementary school-based preventive intervention for conduct problems: Follow-up results from a randomized trial. Behavior Therapy, 34, 525-552. https://doi.org/10.1016/S0005-7894(03)80034-5 
Eisenberg, N., Fabes, R. A., Murphy, B., Maszk, P., Smith, M., \& Karbon, M. (1995). The role of emotionality and regulation in children's social functioning: A longitudinal study. Child development, 66(5), 1360-1384. https://doi.org/10.1111/j.1467-8624.1995.tb00940.x

Elbaum, B. \& Vaughn, S. (2001). School-based interventions to enhance self-concept of students with learning disabilities: A meta-analysis. The Elementary School Journal, 101(3), 303-329. https://doi.org/10.1086/499670

Fenson, L., Pethick, S., Renda, C., Cox, J. L., Dale, P. S., \& Reznick, J. S. (2000). Short-form versions of the MacArthur communicative development inventories. Applied psycholinguistics, 21(1), 95-116. https://doi.org/10.1017/S0142716400001053

Ferretti, L. K., \& Bub, K. L. (2017). Family routines and school readiness during the transition to kindergarten. Early Education and Development, 28, 59-77. https://doi.org/10.1080/10409289.2016.1195671

Fonagy, P., \& Target, M. (1997). Attachment and reflective function: Their role in self-organization. Development and Psychopathology, 9, 679-700. https://doi.org/10.1017/S0954579497001399

Gerdes, K. E., Segal, E. A., \& Lietz, C. A. (2010). Conceptualising and measuring empathy. British Journal Of Social Work, 40, 2326-2343. https://doi.org/10.1093/bjsw/bcq048

Gerrig, R. (1993). Experiencing narrative worlds: On the psychological activities of reading. New Haven, CT: Yale University Press.

Gerrig, R. J., Bagelmann, K. A., \& Mumper, M. L. (2016). On the Origins of Readers' Outcome Preferences. Discourse Processes, 53, 603-631. https://doi.org/10.1080/0163853X.2016.1164001

Glenn, W. J. (2012). Developing understandings of race: Preservice teachers' counter-narrative (re) constructions of people of color in young adult literature. English Education, 44, 326-353.

Goebel, R., Esposito, F., \& Formisano, E. (2006). Analysis of functional image analysis contest (FIAC) data with brainvoyager QX: From single-subject to cortically aligned group general linear model analysis and self-organizing group independent component analysis. Human brain mapping, 27, 392-401. https://doi.org/10.1002/hbm.20249

Gordon, L. K. (2017). The Impact of Multicultural Literature on Empathy Development in Third-Grade Students: A Pilot Study. AERA Online Paper Repository.

Grazzani, I., \& Ornaghi, V. (2011). Emotional state talk and emotion understanding: a training study with preschool children. Journal of Child Language, 38, 1124-1139. https://doi.org/10.1017/S0305000910000772

Grazzani, I., Ornaghi, V., \& Piralli, F. (2011). Teoria della mente e comprensione del lessico psicologico nei bambini: dati preliminari di validazione del Test di Lessico Emotivo (TLE). Psicologia clinica dello sviluppo, 15(1), 257-266. https://dx.doi.org/10.1449/34606

Gresham, F. M., \& Elliott, S. N. (1990). Social skills rating system: Manual. Shoreview, MN: American Guidance Service.

Gresham, F. M., \& Elliott, S. N. (2008). Social skills improvement system: Rating scales manual. San Antonio, TX: NCS Pearson.

Harter, S. (1982). The perceived competence scale for children. Child development, 53(1), 87-97. https://doi.org/10.2307/1129640

Hartung, F., Burke, M., Hagoort, P., \& Willems, R. M. (2016). Taking perspective: Personal pronouns affect experiential aspects of literary reading. PloS one, 11(5). https://doi.org/10.1371/journal.pone.0154732

Hoggan, C., \& Cranton, P. (2015). Promoting transformative learning through reading fiction. Journal of Transformative Education, 13, 6-25. https://doi.org/10.1177/1541344614561864

Houtveen, A. A. M., Smits, A. E. H., \& Brokamp, S. K. (2012). Lezen, lezen, lezen!: Achtergrond en Evaluatie van het LeesInterventie-project voor Scholen met een Totaalaanpak (LIST). Hogeschool Utrecht, Faculteit Educatie, Kenniscentrum Educatie.

Howe, N., Rinaldi, C. M., \& Recchia, H. E. (2010). Patterns in mother-child internal state discourse across four contexts. Merrill Palmer Quarterly, 56, 1-20. https://doi.org/10.1353/mpq.0.0042

Hsu, C. T., Conrad, M., \& Jacobs, A. M. (2014). Fiction feelings in Harry Potter: haemodynamic response in the mid-cingulate cortex correlates with immersive reading experience. Neuroreport, 25, 1356-1361. https://doi.org/10.1097/WNR.0000000000000272 
Hunter, K., \& Bech, B. (2003). Affective empathy in children: Measurement and correlates (Unpublished doctoral dissertation). Queensland: Griffith University

Iacozza, S., Costa, A., \& Duñabeitia, J. A. (2017). What do your eyes reveal about your foreign language? Reading emotional sentences in a native and foreign language. PloS one, 12, e0186027. https://doi.org/10.1371/journal.pone.0186027

Johnson, D. R. (2012). Transportation into a story increases empathy, prosocial behavior, and perceptual bias toward fearful expressions. Personality and Individual Differences, 52, 150-155. https://doi.org/10.1016/j.paid.2011.10.005

Jones, S. M., Brown, J. L., \& Lawrence Aber, J. (2011). Two-year impacts of a universal school-based social-emotional and literacy intervention: An experiment in translational developmental research. Child development, 82, 533-554. https://doi.org/10.1111/j.1467-8624.2010.01560.x

Jongen, I., \& Krom, R. (2009). DMT en AVI: AVI handleiding [DMT and AVI: AVI manual]. Arnhem, CA: Cito.

Junker, R. J., \& Jacquemin, S. J. (2017). How does literature affect empathy in students? College Teaching, 65, 79-87. https://doi.org/10.1080/87567555.2016.1255583

Karniol, R. (2012). Storybook-induced arousal and preschoolers' empathic understanding of negative affect in self, others, and animals in stories. Journal of Research in Childhood education, 26, 346-358. https://doi.org/10.1080/02568543.2012.684423

Kaufman, A. S., \& Kaufman, N. L. (2013). Kaufman brief intelligence test. Encyclopedia of Special Education: A reference for the education of children, adolescents, and adults with disabilities and other exceptional individuals. https://doi.org/10.1002/9781118660584.ese1325

Kidd, D., \& Castano, E. (2013). Reading literary fiction improves theory of mind. Science, 342, 377-380. https://doi.org/10.1126/science. 1239918

Kidd, D., \& Castano, E. (2017). Different stories: How levels of familiarity with literary and genre fiction relate to mentalizing. Psychology of Aesthetics, Creativity, and the Arts, 11, 474-486. https://doi.org/10.1037/aca0000069

Koopman, E. M. E. (2016). Effects of "literariness" on emotions and on empathy and reflection after reading. Psychology of Aesthetics, Creativity, and the Arts, 10, 82. https://doi.org/10.1037/aca0000041

Kozak, S., \& Recchia, H. (2019). Reading and the development of social understanding: Implications for the literacy classroom. The Reading Teacher, 72, 569-577. https://doi.org/10.1002/trtr.1760

Kuijpers, M. M., Hakemulder, F., Tan, E. S., \& Doicaru, M. M. (2014). Exploring absorbing reading experiences: Developing and validating a self-report scale to measure story world absorption. Scientific Study of Literature, 4, 89-122. https://doi.org/10.1075/ssol.4.1.05kui

Kumschick, I. R., Beck, L., Eid, M., Witte, G., Klann-Delius, G., Heuser, I., Steinlein, R., \& Menninghaus, W. (2014). Reading and Feeling: the effects of a literature-based intervention designed to increase emotional competence in second and third graders. Frontiers in Psychology, 5, 1448. https://doi.org/10.3389/fpsyg.2014.01448

Kusche, C. A., Greenberg, M. T., \& Beilke, B. (1988). The Kusche affective interview. Unpublished manuscript, University of Washington, Department of Psychology.

Kvernmo, S. I. V., \& Heyerdahl, S. (1998). Influence of ethnic factors on behavior problems in indigenous Sami and majority Norwegian adolescents. Journal of the American Academy of Child \& Adolescent Psychiatry, 37(7), 743-751. https://doi.org/10.1097/00004583-199807000-00014

Laforge, C., Perron, M., Roy-Charland, A., Roy, É.M., \& Carignan, I. (2018). Contributing to Children's Early Comprehension of Emotions: A Picture Book Approach. Canadian Journal of Education, 41, 301-328.

Lawrence, E. J., Shaw, P., Baker, D., Baron-Cohen, S., \& David, A. S. (2004). Measuring empathy: reliability and validity of the Empathy Quotient. Psychological medicine, $34(5), 911$. https://doi.org/10.1017/S0033291703001624

Lenhard, W., \& Schneider, W. (2006). ELFE 1-6. Ein Leseverständnistest für Erst-bis Sechstklässler. Göttingen: Hogrefe.

Levin, I., \& Bekerman-Greenberg, R. (1980). Moral judgment and moral behavior in sharing: A developmental analysis. Genetic Psychology Monographs, 101(2), 215-230

Lim, H. J., Bong, M., \& Woo, Y. K. (2015). Reading attitude as a mediator between contextual factors and reading behavior. Teachers College Record, 117, 1-36. 
Lochman, J. E., \& Wells, K. C. (2004). The coping power program for preadolescent aggressive boys and their parents: Outcome effects at the 1-year follow-up. Journal of Consulting and Clinical Psychology, 72, 571-578. https://doi.org/10.1037/0022-006X.72.4.571

Lucas, C. P., Zhang, H., Fisher, P. W., Shaffer, D., Regier, D. A., Narrow, W. E., ... \& Lahey, B. B. (2001). The DISC Predictive Scales (DPS): efficiently screening for diagnoses. Journal of the American Academy of Child \& Adolescent Psychiatry, 40(4), 443-449. https://doi.org/10.1097/00004583-200104000-00013

Lysaker, J., \& Tonge, C. (2013). Learning to understand others through relationally oriented reading. The Reading Teacher, 66, 632-641. https://doi.org/10.1002/trtr.1171

Malloy, J. A., Marinak, B. A., Gambrell, L. B., \& Mazzoni, S. A. (2013). Assessing motivation to read: The motivation to read profile-revised. The Reading Teacher, 67(4), 273-282. https://doi.org/10.1002/trtr.1215

Mangen A., \& Kuiken D. (2014). Lost in an iPad: Narrative engagement on paper and tablet. Sci. Study Lit., 4, 150-177. https://doi.org/10.1075/ssol.4.2.02man

Mar, R. A. (2018). Evaluating whether stories can promote social cognition: Introducing the Social Processes and Content Entrained by Narrative (SPaCEN) framework. Discourse Processes, 55(5-6), 454-479. https://doi.org/10.1080/0163853X.2018.1448209

Mar, R. A., \& Oatley, K. (2008). The function of fiction is the abstraction and simulation of social experience. Perspectives on Psychological Science, 3, 173-192. https://doi.org/10.1111/j.1745-6924.2008.00073.x

Mar, R. A., Oatley, K., \& Peterson, J. B. (2009). Exploring the link between reading fiction and empathy: Ruling out individual differences and examining outcomes. Communications, 34, 407-428. https://doi.org/10.1515/COMM.2009.025

Mar, R. A., Oatley, K., Djikic, M., \& Mullin, J. (2011). Emotion and narrative fiction: Interactive influences before, during, and after reading. Cognition and Emotion, 25, 818-833. https://doi.org/10.1080/02699931.2010.515151

Mar, R. A., Oatley, K., Hirsh, J., Dela Paz, J., \& Peterson, J. B. (2006). Bookworms versus nerds: Exposure to fiction versus non-fiction, divergent associations with social ability, and the simulation of fictional social worlds. Journal of Research in Personality, 40, 694-712. https://doi.org/10.1016/j.jrp.2005.08.002

Mar, R. A., Tackett, J. L., \& Moore, C. (2010). Exposure to media and theory-of-mind development in preschoolers. Cognitive Development, 25, 69-78. https://doi.org/10.1016/j.cogdev.2009.11.002

Marsh, H. W. (1990). Self Description Questionnaire-III: SDQ III Manual. University of Western Sydney, Toronto, Ontario: Macarthur.

Masten, A. S., \& Cicchetti, D. (2010). Developmental cascades. Development and Psychopathology, 22, 491-495. https://doi.org/10.1017/S0954579410000222

McCreary, J. J., \& Marchant, G. J. (2017). Reading and empathy. Reading Psychology, 38, 182-202. https://doi.org/10.1080/02702711.2016.1245690

Meins, E., Fernyhough, C., Arnott, B., \& Leekam, S. (2013). Mind-mindedness and theory of mind: Mediating roles of language and perspectival symbolic play. Child Development, 84, 1777-1790. https://doi.org/10.1111/cdev.12061

Mendelsohn, A. L., Mogilner, L. N., Dreyer, B. P., Forman, J. A., Weinstein, S. C., Broderick, M., et al. (2001). The impact of a clinic-based literacy intervention on language development in inner-city preschool children. Pediatrics, 107, 130-134. https://doi.org/10.1542/peds.107.1.130

Milich, R., Loney, J., \& Landau, S. (1982). Independent dimensions of hyperactivity and aggression: A validation with playroom observation data. Journal of Abnormal Psychology, 91(3), 183-198. https://doi.org/10.1037/0021-843X.91.3.183

Moher, D., Liberati, A., Tetzlaff, J., \& Altman, D. G. (2009). Linee guida per il reporting di revisioni sistematiche e meta-analisi: il PRISMA Statement. PLoS Med, 6. https://doi.org/10.1371/journal.pmed.1000097

Morgan, P. L., Farkas, G., \& Wu, Q. (2012). Do poor readers feel angry, sad, and unpopular?. Scientific Studies of Reading, 16(4), 360-381. https://doi.org/10.1080/10888438.2011.570397

Mumper, M. L., \& Gerrig, R. J. (2017). Leisure reading and social cognition: A meta-analysis. Psychology of Aesthetics, Creativity, and the Arts, 11, 109-120. https://doi.org/10.1037/aca0000089

Mumper, M. L., \& Gerrig, R. J. (2019). How Does Leisure Reading Affect Social Cognitive Abilities?. Poetics Today, 40(3), 453-473. https://doi.org/10.1215/03335372-7558080 
Murray, A., \& Egan, S. M. (2014). Does reading to infants benefit their cognitive development at 9-months-old? An investigation using a large birth cohort survey. Child Lang. Teach. Ther., 30, 303-315. https://doi.org/10.1177/0265659013513813

National Research Council. (1998). Preventing reading difficulties in young children. Washington, DC: National Academies Press. https://doi.org/10.17226/6023

Nord, C., Edwards, B., Hilpert, R., Branden, L., Andreassen, C. Elmore, A., ... \& West, J. (2004). Early Childhood Longitudinal Study, Birth Cohort (ECLS-B), User's Manual for the ECLS-B Nine-Month Restricted-Use Data File and Electronic Code Book (NCES 2004-092). U.S. Department of Education. Washington, DC: National Center for Education Statistics.

Nowicki, S. J. (2007). A Manual for the DANVA Tests. Atlanta, GA: Department of Psychology, Emory University.

Nowicki, S. J., \& Carton, J. (1993). The measurement of emotional intensity from facial expressions: The DANVA FACES 2. Journal of Social Psychology, 133, 749-750. https://doi.org/10.1080/00224545.1993.9713934

Oatley, K. (1999). Meeting of minds: Dialogue, sympathy, and identification in reading fiction. Poetics, 26, 439-454. https://doi.org/10.1016/S0304-422X(99)00011-X

Oppenheim, D., Emde, R. N., \& Warren, S. (1997). Children's narrative representations of mothers: Their development and associations with child and mother adaptation. Child development, 68(1), 127-138. https://doi.org/10.1111/j.1467-8624.1997.tb01930.x

Organization for Economic Co-operation and Development. (2010). PISA 2009 results: Learning to learn. Student engagement, strategies and practices. Retrieved from https://www.oecd.org/pisa/pisaproducts/48852630.pdf

Ornaghi, V., Brockmeier, J., \& Grazzani, I. (2014). Enhancing social cognition by training children in emotion understanding: A primary school study. Journal of Experimental Child Psychology, 119, 26-39. https://doi.org/10.1016/j.jecp.2013.10.005

Panero, M. G., Weisberg, D. S., Black, J., Goldstein, T. R., Barnes, J. L., Brownell, H., \& Winner, E. (2016). Does reading a single passage of literary fiction really improve theory of mind? An attempt at replication. Journal of Personality and Social Psychology, 111(5), e46-e56. https://doi.org/10.1037/pspa0000064

Pang, W. C., \& Zhang, K. C. (2011). Reading intervention for secondary students with hyperactive behaviours in Hong Kong. Emotional and behavioural difficulties, 16, 69-85. https://doi.org/10.1080/13632752.2011.545644

Paris, A. H., \& Paris, S. G. (2003). Assessing narrative comprehension in young children. Reading Research Quarterly, 38(1), 36-76. https://doi.org/10.1598/RRQ.38.1.3

Paulus, C. (2009). Der Saarbrücker Persönlichkeitsfragebogen SPF (IRI) zur messung von empathie: psychometrische evaluation der deutschen version des interpersonal reactivity index. Saarbrücken, Universität des Saarlandes. Retrived from https://psydok.psycharchives.de/jspui/bitstream/20.500.11780/3343/3/SPF_Artikel.pdf

Pelletier, J., \& Astington, J. W. (1998). Metacognitive vocabulary test. Unpublished ms., Institute for Child Studies, University of Toronto

Peskin, J., \& Astington, J. W. (2004). The effects of adding metacognitive language to story texts. Cognitive development, 19(2), 253-273. https://doi.org/10.1016/j.cogdev.2004.01.003

Petrides, K. V., Sangareau, Y., Furnham, A., \& Frederickson, N. (2006). Trait emotional intelligence and children's peer relations at school. Social Development, 15, 537-547. https://doi.org/10.1111/j.1467-9507.2006.00355.x

Pollack, J. M., Najarian, M., Rock, D. A., \& Atkins-Burnett, S. (2005). Early Childhood Longitudinal Study, Kindergarten Class of 1998/99 (ECLS-K). Psychometric Report for the Fifth Grade (NCES 2006-036). U.S. Department of Education. Washington, DC: National Center for Education Statistics. https://doi.org/10.1037/e428752005-001

Pons, F., \& Harris, P. (2000). Test of Emotion Comprehension - TEC. Oxford, UK: Oxford University Press.

Pons, F., Harris, P. L., \& de Rosnay, M. (2004). Emotion comprehension between 3 and 11 years: Developmental periods and hierarchical organization. European Journal of Developmental Psychology, 1, 127-152. https://doi.org/10.1080/17405620344000022

Premack, D., \& Woodruff, G. (1978). Does the chimpanzee have a theory of mind? The Behavioral and Brain Science, 1, 515-526. https://doi.org/10.1017/S0140525X00076512

Pytash, K. E. (2013). Using YA literature to help preservice teachers deal with bullying and suicide. Journal of adolescent \& adult literacy, 56, 470-479. https://doi.org/10.1002/JAAL.168 
Reschly, A. L. (2010). Reading and school completion: Critical connections and Matthew effects. Reading \& Writing Quarterly, 26(1), 67-90. https://doi.org/10.1080/10573560903397023

Reynolds, C. R., \& Kamphaus, R. W. (1998). BASC: Behavior assessment system for children: Manual. Shoreview, MN: American Guidance Service.

Riquelme, E., \& Montero, I. (2013). Improving emotional competence through mediated reading: Short term effects of an infantile literature program. Mind, Culture, and Activity, 20, 226-239. https://doi.org/10.1080/10749039.2013.781185

Riquelme, E., \& Montero, I. (2016). Long-term effects of a mediated reading programme on the development of emotional competencies/Efectos a largo plazo de un programa de lectura mediada para el desarrollo de competencias emocionales. Cultura y Educación, 28, 435-467. https://doi.org/10.1080/11356405.2016.1196900

Riquelme, E., Munita, F., Jara, E., \& Montero, I. (2013). Reconocimiento facial de emociones y desarrollo de la empatía mediante la Lectura Mediada de literatura infantil. Cultura y Educación, 25, 375-388. https://doi.org/10.1174/113564013807749704

Salceda, J. C. R., Alonso, G. A., \& Castilla-Earls, A. P. (2014). The simple view of reading in elementary school: A systematic review. Revista de Logopedia, Foniatría y Audiología, 34, 17-31. https://doi.org/10.1016/j.rlfa.2013.04.006

Samur, D., Tops, M., \& Koole, S. L. (2018). Does a single session of reading literary fiction prime enhanced mentalising performance? Four replication experiments of Kidd and Castano (2013), Cognition and Emotion, 32(1), 130-144. https://doi.org/10.1080/02699931.2017.1279591

Santos, R. M., Fettig, A., \& Shaffer, L. (2012). Helping families connect early literacy with socio-emotional development. Young Children, 67, 88-93.

Schapira, R., \& Aram, D. (2019). Shared book reading at home and preschoolers' socio-emotional competence. Early Education and Development, 1-19. https://doi.org/10.1080/10409289.2019.1692624

Shields, A., \& Cicchetti, D. (1997). Emotion regulation among school-age children: The development and validation of a new criterion Q-sort scale. Developmental psychology, 33(6), 906-916. https://doi.org/10.1037/0012-1649.33.6.906

Shonkoff, J. P., \& Phillips, D. A. (2000). From neurons to neighborhoods: The science of early childhood development. Washington, DC: National Academies Press. www.nap. edu/catalog.php?record_id=9824

Slay, L. E., \& Morton, T. B. (2020). Engaging Pre-Service Teachers in Read Alouds. Changing English, 27, 64-82. https://doi.org/10.1080/1358684X.2019.1710696

Smetana, J. G. (1981). Preschool children's conceptions of moral and social rules. Child development, 52(4), 1333-1336. https://doi.org/10.2307/1129527

Smits, J. A. E., \& Vorst, H. C. M. (2008). Schoolvragenlijst (Dutch School Questionnaire). Amsterdam: Pearson

Spinrad, T. L., Losoya, S. H., Eisenberg, N., Fabes, R. A., Shepard, S. A., Cumberland, A., ... Murphy, B. C. (1999). The relations of parental affect and encouragement to children's moral emotions and behaviour. Journal of Moral Education, 28(3), 323-337. https://doi.org/10.1080/030572499103115

Stepien, K. A. \& Baernstein. A. (2006). Educating for empathy. A review. Journal of General Internal Medicine, 21, 524-530. https://doi.org/10.1111/j.1525-1497.2006.00443.x

Stutler, S. L. (2011). Gifted girls' passion for fiction: The quest for meaning, growth, and self-actualization. Gifted Child Quarterly, 55, 18-38. https://doi.org/10.1177/0016986210383979

Tabullo, A. J., Jiménez, V. A. N., \& García, C. S. (2018). Associations between fiction Reading, trait empathy and theory of mind ability. International journal of psychology and psychological therapy, 18, 357-370.

Taghavi, M. R., Neshat-Doost, H. T., Moradi, A. R., Yule, W., \& Dalgleish, T. (1999). Biases in visual attention in children and adolescents with clinical anxiety and mixed anxiety-depression. Journal of Abnormal Child Psychology, 27(3), 215-223 https://doi.org/10.1023/A:1021952407074

Talairach, J., and Tournoux, P. (1988). Co-Planar Stereotaxic Atlas of the Human Brain. New York, NY: Thieme.

Tijms, J., Stoop, M. A., \& Pollock, J. N. (2018). Bibliotherapeutic book club intervention to promote reading skills and social-emotional competencies in low SES community-based high schools: A randomised controlled trial. Journal of Research in Reading, 41, 525-545. https://doi.org/10.1111/1467-9817.12123 
Tomé-Fernández, M., Senís-Fernández, J., \& Ruiz-Martín, D. (2019). Values and intercultural experiences through picture books. The Reading Teacher, 73, 205-213. https://doi.org/10.1002/trtr.1813

Undheim, A. M., Wichstrøm, L., \& Sund, A. M. (2011). Emotional and behavioral problems among school adolescents with and without reading difficulties as measured by the youth self-report: A one-year follow-up study. Scandinavian journal of educational research, 55, 291-305. https://doi.org/10.1080/00313831.2011.576879

van Doorn, F. (2000). Gedragsijist [Behavior questionnaire]. Amsterdam: ABC.

VanSledright, B., Kelly, T., \& Meuwissen, K. (2006). Oh, the trouble we've seen: Researching historical thinking and understanding. In K. Barton (Ed.), Research methods in social studies education: Contemporary issues and perspectives (pp. 207-233). Greenwich, CT: Information Age.

Venegas, E. M. (2019). "We Listened to Each Other": Socioemotional Growth in Literature Circles. The Reading Teacher, 73, 149-159. https://doi.org/10.1002/trtr.1822

Volpi, J. (2011). Leer La Mente. El Cerebro Y El Arte De La Ficción [Mind Reading. The Brain and The Art of Fiction]. Madrid: Alfaguara.

Wallot, S., O'Brien, B. A., Haussmann, A., Kloos, H., \& Lyby, M. S. (2014). The role of reading time complexity and reading speed in text comprehension. Journal of Experimental Psychology-Learning Memory and Cognition, 40, 1745-1765. https://doi.org/10.1037/xlm0000030

Wulandini, Kuntoro, I. A., \& Handayani, E. (2018). The effect of literary fiction on school-aged children's theory of mind (ToM). In A. A. Ariyanto, H. Muluk, P. Newcombe, F. P. Piercy, E. K. Poerwandari, \& S. H. R. Suradijono (Eds.), Diversity in unity: Perspectives from psychology and behavioral sciences (pp. 159-166). London, UK: Routledge. https://doi.org/10.1201/9781315225302-20

Yussof, Y. M., Jamian, A. R., Hamzah, Z. A. Z., \& Roslan, S. (2013). Students' Reading Comprehension Performance with Emotional Literacy-Based Strategy Intervention. International Journal of Education and Literacy Studies, 1, 82-88. https://doi.org/10.7575/aiac.ijels.v.1n.1p.82 


\section{Appendix A}

Table 4. Descriptive Results of Childhood

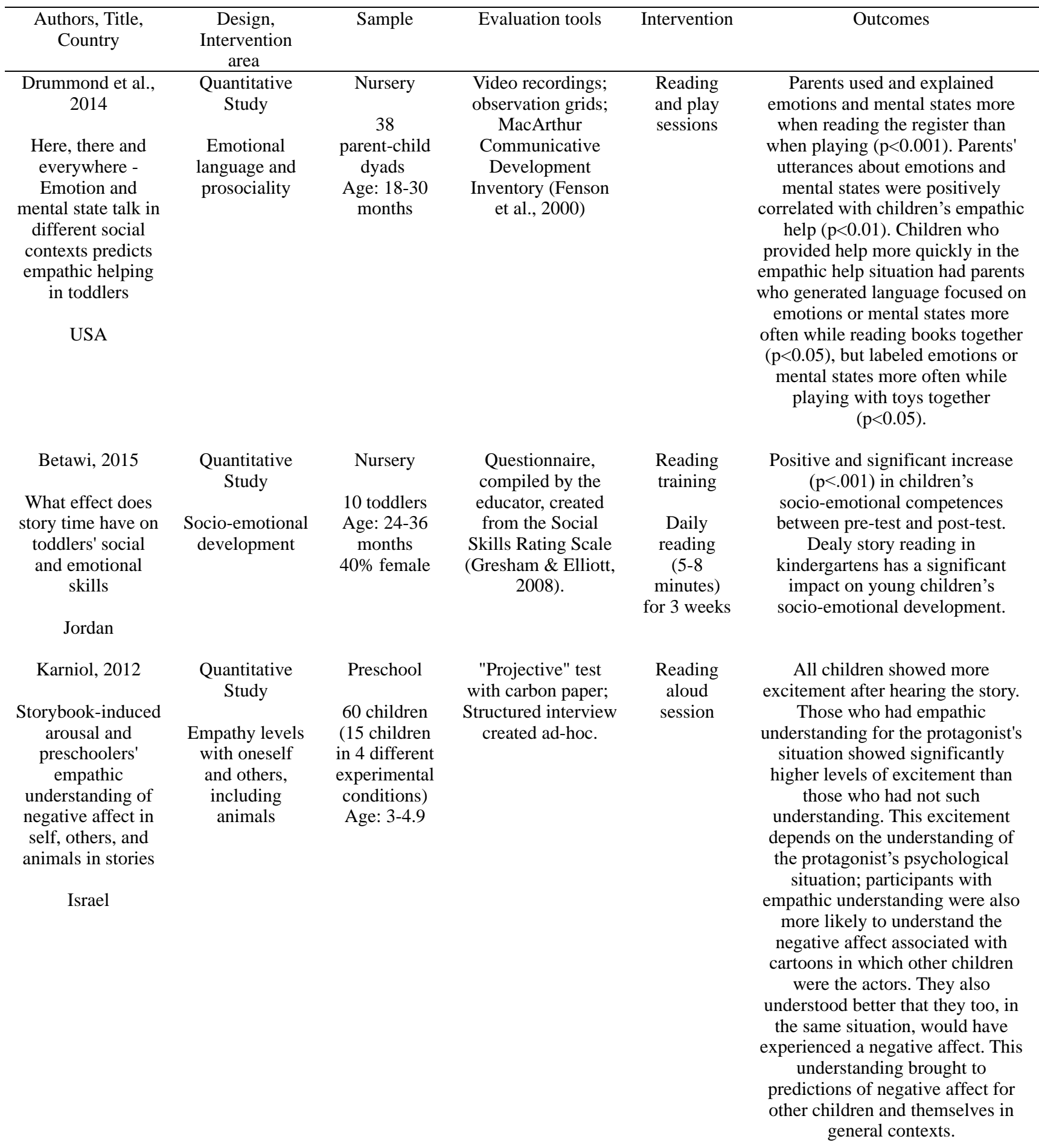




\section{Laforge et al., 2018
Contributing to children's early emotions: A picture book approach \\ comprehension of}

France

\author{
Grazzani \& \\ Ornaghi, 2011 \\ Emotional state \\ talk and emotion \\ understanding: \\ A training study \\ with preschool \\ children
}

Italy

\section{Baker, 2013 \\ Fathers' and mothers' home literacy involvement and children's cognitive and social emotional development: Implications for family literacy programs}

\section{USA}

Schapira \& Aram, 2019

\section{Shared book} reading at home and preschoolers' socioemotional competence

Israel

Quantitative
Study
Reading and
emotions
comprehension

Preschoo

18 children

Experimental:

9 children; $\mathrm{M}$ : 41.88

months;

$77.7 \%$ female

Control:

9 children; M:

40 months;

$77.7 \%$ female

Quantitative
Study
Language of
emotional
theory of mind

\section{Preschool}

100 children

Experimental:

50 children;

M: 52.55

months

Control:

50 children;

M: 51.52

months

Preschool

Quantitative

Longitudinal Study

Literacy and socio-emotional development

5190 children M: 52 months $67.1 \%$ female

$$
\begin{gathered}
\text { Quantitative } \\
\text { Study } \\
\text { Reading and } \\
\text { socio-emotional } \\
\text { competence }
\end{gathered}
$$

Preschool
50
kindergarten
children
M: 55.64
months
$48 \%$ female

50 parents
$88 \%$ female

Semi-structured naturalistic interview during a game;

Interview after watching parts of a film, scaled answers;

MacArthur Story Stem Battery (MSSB)

(Oppenheim et al., 1997).

Metacognitive Verb
Reading training

7 times in three weeks

Reading training

2 months

No intervention

Reading sessions

2 weeks evaluated socio-emotional outcomes $(\mathrm{p}<0.05 ; \mathrm{p}<0.01)$. The parents' general statements explained empathy and social coherence $(\mathrm{p}<0.05)$.

Children's socio-emotional and general statements during SBR significantly explained all socio-emotional outcomes $(\mathrm{p}<0.05$; $p<0.01$ ), except for the causes of emotions $(\mathrm{p}=0.06)$.

Language level and children's age explained children's empathy $(\mathrm{r}=.29, \mathrm{p}=.05)$ and the SES explained children's social coherence. 


\author{
Ferretti \& Bub, \\ 2017 \\ Family routines \\ and school \\ readiness during \\ the transition to \\ kindergarten
}

USA

\author{
Baker \& \\ Rimm-Kaufman, \\ 2014 \\ How homes \\ influence schools: \\ Early parenting \\ predicts African \\ American \\ children's \\ classroom \\ social-emotional \\ functioning
}

USA

Aram et al., 2017

\section{Shared book reading}

interactions within

families from low

socioeconomic

backgrounds and

children's social

understanding and

prosocial behavior

Israel

Quantitative
Longitudinal
study
Literacy and
socio-emotional
development

Preschool old

$50 \%$ female

development

(

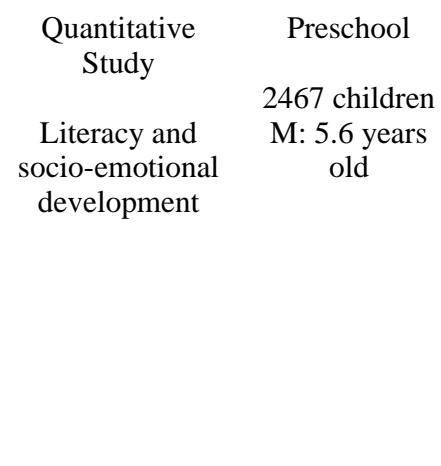

\section{Quantitative Preschool Study \\ Socio-emotional development \\ kindergarten children with their mothers M: 5.8 years old}

$50 \%$ female

$$
\begin{gathered}
\text { Beazidou et. al., } \\
2013
\end{gathered}
$$

\section{Promoting emotional} knowledge: Strategies that Greek preschool teachers employ during book reading

Greece

$\begin{array}{cc}\text { Qualitative } & \text { Preschool } \\ \text { Study } & 224 \\ \text { Reading and } & \text { kindergarten } \\ \text { emotional } & \text { children and } \\ \text { knowledge } & 12 \text { teachers }\end{array}$

3250 children

M: 5.67 years

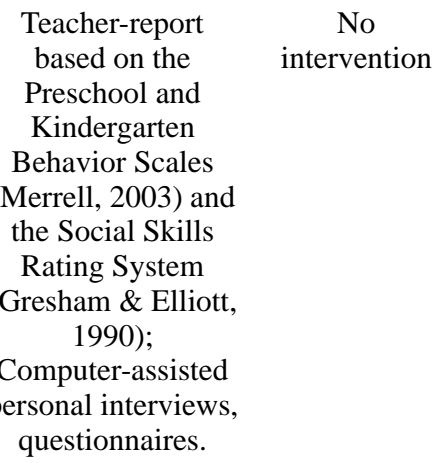

No

Scale (Gresham \& intervention Elliott, 1990);

Home Observation

for Measurement of the Environment scale (Caldwell et al., 1984).
Video recordings of mother-child interactions;
A measure based on drawings
representing social norms or moral violations (Smetana, 1981);
Reading sessions
Two weekly sessions for a fortnight (30-40 minutes)

Observations of a sharing game with a friend (Levin \& Bekerman

Greenberg, 1980).

Classroom observation; Audio recordings at reading time; Interviews.
Reading training

25 minutes for reading session
Maternal warmth was positively correlated $(\mathrm{p}<.05)$ with mothers' learning stimulation at home (shared book reading, visits to the library, singing songs, storytelling and providing educational opportunities). Mothers' learning stimulation predicted a better approach to learning $(\mathrm{p}<.001)$, better self-control and interpersonal skills $(\mathrm{p}<.005 ; \mathrm{p}<.001)$, and less externalizing behaviors $(\mathrm{p}<.005)$ in children.

$$
\begin{aligned}
& \text { After reading, decontextualized } \\
& \text { references prevailed both in } \\
& \text { mothers }(\mathrm{p}<.001) \text { and in children } \\
& \text { ( } \mathrm{p}<.05) \text {. These references are } \\
& \text { associated in literature to better } \\
& \text { socio-emotional development. } \\
& \text { References by mothers and } \\
& \text { children to the book's } \\
& \text { socio-emotional contents were } \\
& \text { associated with greater } \\
& \text { socio-emotional understanding } \\
& \text { ( } \mathrm{p}<.05 \text { ) and prosocial behavior } \\
& \text { (p<.05) in children. When mothers } \\
& \text { and children used more } \\
& \text { socio-emotional contents, children } \\
& \text { showed greater social } \\
& \text { understanding ( }<<.05 \text { ) and more } \\
& \text { prosocial behavior ( }<<.05 \text { ) than } \\
& \text { children belonging to dyads in } \\
& \text { which less socio-emotional } \\
& \text { contents were used. }
\end{aligned}
$$

Two main strategies: simple dialogues and active participation with more complex conversations.

Teachers tried to build a new emotive vocabulary; movements and voice were used as educational techniques to mediate emotional understanding and expression; they asked to find the cause of an emotion, to compare the different characters' feelings and to imagine what will happen next. Another strategy was to focus on children's personal emotions while reading. 


\begin{tabular}{|c|c|c|c|c|c|}
\hline $\begin{array}{l}\text { Riquelme \& } \\
\text { Montero, } 2016\end{array}$ & $\begin{array}{l}\text { Quantitative } \\
\text { Study }\end{array}$ & $\begin{array}{l}\text { From } \\
\text { preschool to } \\
\text { second grade }\end{array}$ & $\begin{array}{l}\text { Diagnostic Analysis } \\
\text { of Nonverbal } \\
\text { Accuracy-2 }\end{array}$ & $\begin{array}{l}\text { Reading } \\
\text { training }\end{array}$ & $\begin{array}{l}\text { Emotional skills in the mediated } \\
\text { reading group increased compared }\end{array}$ \\
\hline $\begin{array}{l}\text { Long-term effects } \\
\text { of a mediated } \\
\text { reading } \\
\text { programme on the } \\
\text { development of } \\
\text { emotional } \\
\text { competences } \\
\text { Chile }\end{array}$ & $\begin{array}{l}\text { Reading and } \\
\text { emotional } \\
\text { competence } \\
\text { (recognition, } \\
\text { regulation and } \\
\text { empathy) }\end{array}$ & $\begin{array}{c}50 \text { children } \\
55.6-96.83 \\
\text { months } \\
\text { divided into } \\
\text { experimental } \\
\text { group } \\
\text { (mediated } \\
\text { reading) and } \\
\text { control group } \\
\text { (traditional } \\
\text { reading); } \\
\text { characteristic } \\
\text { s not } \\
\text { specified }\end{array}$ & $\begin{array}{c}\text { (DANVA-2); } \\
\text { (Nowicki, 2007); } \\
\text { Griffith Empathy } \\
\text { Measure-Parent } \\
\text { Report (GEM-PR); } \\
\text { (Hunter \& Bech, } \\
\text { 2003); Emotion } \\
\text { Regulation } \\
\text { Checklist (ERC); } \\
\text { (Shields \& } \\
\text { Cicchetti, 1997). }\end{array}$ & $\begin{array}{l}8 \text { months } \\
\text { (two } \\
\text { reading } \\
\text { sessions per } \\
\text { week each } \\
\text { lasting } \\
25-40 \\
\text { minutes) }\end{array}$ & $\begin{array}{l}\text { Recognition of emotions: } \\
\text { significant effect in the interaction } \\
\text { between "Treatment" and } \\
\text { "Evaluation" ( } \mathrm{p}<.01) \text { and in the } \\
\text { interaction between "Degree" and } \\
\text { "Treatment" ( }<<.05) \text {. Empathy: } \\
\text { significant, although marginal, } \\
\text { fourfold interaction between the } \\
\text { factors Evaluation, Treatment, } \\
\text { Degree and Sex ( } \mathrm{p}=.07) \text {. Emotional } \\
\text { regulation: it shows a significant } \\
\text { effect on the interaction } \\
\text { "Treatment" and } \\
\text { "Evaluation"(p<.01), as well as in } \\
\text { the interaction between the factors } \\
\text { "Degree" and "Treatment" ( }<<.01) \text {. } \\
\text { Higher results were found in the } \\
\text { childhood group. Improvements } \\
\text { were also found in the control } \\
\text { group, although lower. }\end{array}$ \\
\hline $\begin{array}{l}\text { Riquelme et al., } \\
2013\end{array}$ & $\begin{array}{l}\text { Quantitative } \\
\text { Study }\end{array}$ & $\begin{array}{l}\text { From } \\
\text { preschool to } \\
\text { primary }\end{array}$ & $\begin{array}{l}\text { Diagnostic Analysis } \\
\text { of Nonverbal } \\
\text { Accuracy }\end{array}$ & $\begin{array}{l}\text { Reading } \\
\text { training }\end{array}$ & $\begin{array}{l}\text { The intervention had a significant } \\
\text { impact on children in the mediated } \\
\text { reading group, where facial }\end{array}$ \\
\hline $\begin{array}{l}\text { Reconocimiento } \\
\text { facial de } \\
\text { emociones y } \\
\text { desarrollo de la } \\
\text { empatía mediante } \\
\text { la lectura } \\
\text { mnediada de } \\
\text { literatura infantil }\end{array}$ & $\begin{array}{l}\text { Mediated } \\
\text { reading and } \\
\text { emotional } \\
\text { competence } \\
\text { (Facial } \\
\text { recognition of } \\
\text { emotion and } \\
\text { Empathy) }\end{array}$ & $\begin{array}{c}\text { school } \\
101 \text { children } \\
\\
\text { Experimental: } \\
24 \\
\text { kindergarten } \\
\text { children; M: } \\
65.75\end{array}$ & $\begin{array}{c}\text { (DANVA-2) - } \\
\text { abbreviated version } \\
\text { (Nowicki, 2007; } \\
\text { Nowicki \& Carton, } \\
\text { 1993); } \\
\text { Griffith's empathy } \\
\text { (GEM-PR) (Dadds } \\
\text { et al., 2008). }\end{array}$ & $\begin{array}{l}5 \text { months } \\
\text { (two } \\
\text { sessions on } \\
\text { week of } \\
25-40 \\
\text { minutes) }\end{array}$ & $\begin{array}{c}\text { recognition skills of emotions } \\
\text { (Childhood group: } \mathrm{p}<.01 ; \text { Primary } \\
\text { group: } \mathrm{p}<.01 \text { ) and empathy } \\
\text { (Childhood group: } \mathrm{p}<.01 ; \text { Primary } \\
\text { group: } \mathrm{p}<.01 \text { ) are increased in } \\
\text { comparison to the traditional } \\
\text { reading group. }\end{array}$ \\
\hline \multirow[t]{2}{*}{ Chile } & & $\begin{array}{c}\text { months; } \\
66,66 \% \\
\text { female } \\
30 \text { primary } \\
\text { students; } \mathrm{M}: \\
75.61 \\
\text { months; } 40 \% \\
\text { female }\end{array}$ & & & \\
\hline & & $\begin{array}{c}\text { Control: } \\
18 \\
\text { kindergarten } \\
\text { children; M: } \\
66.19 \\
\text { months; } \\
50 \% \text { female } \\
29 \text { primary } \\
\text { students; } \\
\text { M: } 75.79 \\
\text { months; } \\
55.1 \% \text { female }\end{array}$ & & & \\
\hline
\end{tabular}




\section{Appendix B}

Table 5. Descriptive Results in School-age

\begin{tabular}{|c|c|c|c|c|c|}
\hline $\begin{array}{c}\text { Authors, Title, } \\
\text { Country }\end{array}$ & $\begin{array}{c}\text { Design, } \\
\text { Intervention } \\
\text { area }\end{array}$ & Sample & Evaluation tools & Intervention & Outcomes \\
\hline $\begin{array}{c}\text { Riquelme \& } \\
\text { Montero, } 2013 \\
\text { Improving } \\
\text { emotional } \\
\text { competence } \\
\text { through mediated } \\
\text { reading: Short } \\
\text { term effects of a } \\
\text { children's } \\
\text { literature } \\
\text { program } \\
\text { Spain, Chile }\end{array}$ & $\begin{array}{l}\text { Quantitative } \\
\text { Study } \\
\text { Mediated } \\
\text { reading and } \\
\text { emotional } \\
\text { competence }\end{array}$ & $\begin{array}{c}\text { Primary } \\
\text { School } \\
\text { (first grade) } \\
92 \text { students } \\
\text { M: } 6.7 \text { years } \\
\text { old } \\
\text { Experimental: } \\
44 \text { students; } \\
43.18 \% \text { female } \\
\text { Control: } \\
30 \text { students; } \\
36.66 \% \\
\text { female; } \\
\text { 18 students; } \\
38.88 \% \text { female }\end{array}$ & $\begin{array}{l}\text { Diagnostic Analysis } \\
\text { of Non Verbal } \\
\text { Accuracy-2 } \\
\text { (DANVA-2) } \\
\text { Nowicki, 2007); } \\
\text { Emotional } \\
\text { Regulation } \\
\text { Checklist (ER) } \\
\text { (Shields \& } \\
\text { Cicchetti, 1997); } \\
\text { Griffith Empathy } \\
\text { Measure (GEM-PR) } \\
\text { (Hunter \& Bech, } \\
\text { 2003). }\end{array}$ & $\begin{array}{l}\text { Reading } \\
\text { training } \\
4 \text { months } \\
\text { (two weekly } \\
\text { meetings) }\end{array}$ & $\begin{array}{l}\text { The mediated reading program had } \\
\text { a significant effect on all the } \\
\text { variables indicated with respect to } \\
\text { the control groups: recognition of } \\
\text { emotions }(\mathrm{p}<.01) \text {, empathy } \\
\text { (p<.01), emotional lability }(\mathrm{p}<.01) \text {. }\end{array}$ \\
\hline $\begin{array}{l}\text { Casserly, } 2011 \\
\text { Children's } \\
\text { experiences of } \\
\text { reading classes } \\
\text { and reading } \\
\text { schools in Ireland } \\
\text { Ireland }\end{array}$ & $\begin{array}{l}\text { Longitudinal } \\
\text { Qualitative } \\
\text { Study } \\
\text { Reading } \\
\text { Experience } \\
\text { and socio- } \\
\text { emotional } \\
\text { factors }\end{array}$ & $\begin{array}{l}\text { Primary school } \\
20 \text { students } \\
\text { Age: } 6-7\end{array}$ & $\begin{array}{c}\text { Semi-structured } \\
\text { interview created } \\
\text { ad-hoc. }\end{array}$ & $\begin{array}{l}\text { Special } \\
\text { Reading } \\
\text { Program }\end{array}$ & $\begin{array}{l}\text { Children were aware of their } \\
\text { inadequacies, particularly when } \\
\text { they read in front of their peers in } \\
\text { class. Almost half of the children } \\
\text { felt that their peers were aware of } \\
\text { their difficulties, but were } \\
\text { empathetic towards them. In some } \\
\text { cases, children felt embarrassed, } \\
\text { especially when others laughed } \\
\text { that they were losing their mark in } \\
\text { reading. They also reported that } \\
\text { they had improved their self-help } \\
\text { strategies and referred to their } \\
\text { determination to solve problems. }\end{array}$ \\
\hline $\begin{array}{l}\text { Angantyr et al., } \\
2016 \\
\text { Reducing sex } \\
\text { differences in } \\
\text { children's } \\
\text { empathy for } \\
\text { animals through } \\
\text { a training } \\
\text { intervention } \\
\text { Sweden }\end{array}$ & $\begin{array}{l}\text { Quantitative } \\
\text { study } \\
\text { Reading-based } \\
\text { empathy } \\
\text { programme }\end{array}$ & $\begin{array}{l}\text { Primary school } \\
137 \text { students } \\
\text { Age: } 5-11 \\
\text { Experimental: } \\
\quad 80 \\
\text { Control: } 57\end{array}$ & $\begin{array}{l}\text { 7-point Likert-type } \\
\text { scale, created ad-hoc } \\
\text { to measure Grade of } \\
\text { empathy }\end{array}$ & $\begin{array}{l}\text { Reading } \\
\text { session }\end{array}$ & $\begin{array}{l}\text { Girls showed more empathy than } \\
\text { boys ( } \mathrm{p}<.01 \text { ). This main effect was } \\
\text { qualified by a significant } \\
\text { interaction effect between gender } \\
\text { and condition in the group } \\
\text { ( } \mathrm{p}<.05 \text { ). However, in the } \\
\text { experimental group, it was not } \\
\text { statistically significant. Children } \\
\text { who own a dog showed more } \\
\text { empathy than children who do not. } \\
\text { In this case, a significant gender } \\
\text { effect was recorded for girls. } \\
\text { Age/Empathy: negative correlation } \\
\text { (p<.07), the youngest show more } \\
\text { empathy). Joy/Empathy: negative } \\
\text { correlation confirmed (p<.01). } \\
\text { This suggests that human } \\
\text { education programs can reduce } \\
\text { gender differences by increasing } \\
\text { boys' empathy. }\end{array}$ \\
\hline
\end{tabular}




Ornaghi et al.,
2014
Enhancing social
cognition by
training children
in emotion
understanding: A
primary school
study
Italy


tongitudinal links
to children's
socioemotional
competence
families and
American
Chinese
Emotis et al., 2020

USA

Quantitative
Study
Reading and
understanding
emotions,
theory of mind
and empathy

Primary

School

(second grade)

110 students

M: 7.3 years old

$50 \%$ female

Experimental:

52 students;

Control:

58 students;

$51.9 \%$ female

Emotional Lexicon
Test (ELT)
(Grazzani, Ornaghi,
\& Piralli, 2011);

Reading

training

2 months (15

1-hour

sessions,

Comprehension

(TEC) - Italian

version (Albanese \&

Molina (2008);

False belief battery

(FB Battery) (Peskin

\& Astington, 2004);

How I Feel in

Different Situations

(HIFDS) - Italian

version (Bonino, Lo

Coco, and Tani, 1998).

twice a week

in small

groups)

Follow up 6 months

Longitudinal
Quantitative
Study
Parent emotion
talk (ET) and
socio-
emotional
skills

\section{Primary \\ School}

Two waves:

(W1) 207

190 children.

207 children

M: 7.4 years

old

$50.7 \%$ female
Child Report of

Sympathy Scale

(Spinrad et al.,

1999); Adapted

Social Competence

Scale of the

Perceived Social

Competence Scale

(Eisenberg et al.,

1995; Harter, 1982).
$53.8 \%$ female

children, (W2)
Reading sessions

(Two waves at a distance of 1,5 years; laboratory evaluation 2.5 - 3 hours)
Positive effects of the intervention; participants showed significant gains in their emotions comprehension $(\mathrm{p}=.0001)$, theory of mind $(\mathrm{p}=.0002)$ and emotional vocabulary $(\mathrm{p}=.005)$.

The experimental group achieved significantly better results than the control group for the overall TEC score, $(\mathrm{p}=.000001)$, the reflexive component ( $\mathrm{p}=.000001)$. With regard to overall TEC

performance, the size of the effect identified at post-test ( $\mathrm{d}$ by

Cohen=0.80; $r=.37$ ) was stable at follow-up ( $\mathrm{d}$ by Cohen=1.03; $r=.46)$. The scores for the reflection level also showed a stable effect size at post-test, (Cohen $\mathrm{d}=0.86 ; \mathrm{r}=.39$ ) and at follow-up (Cohen $\mathrm{d}=1.02 ; \mathrm{r}=.45)$.

ET was positively correlated (rs=0.12 to 0.74). The use of positively emotional words by parents and the quality of ET were positively correlated with self-control (rs=0.19 and 0.17) and children's understanding ( $\mathrm{rs}=0.16$ and 0.15 ) reported by teachers.

Parents' use of positive emotional words was positively correlated with children's social behavior reported by parents in $\mathrm{W} 2(\mathrm{r}=$

$0.17)$. Positive correlation between parents' ET in W1 and children's self-control in W2. Even excluding social behavior in W1, the ET of parents in $\mathrm{W} 1$ positively predicts children's self-control in W2.

Self-control in W2 was positively associated with social behavior in W2.

\begin{tabular}{|c|c|c|}
\hline $\begin{array}{c}\text { Lysaker \& Tonge, } \\
2013\end{array}$ & $\begin{array}{c}\text { Quantitative } \\
\text { Study }\end{array}$ & $\begin{array}{l}\text { Primary } \\
\text { School }\end{array}$ \\
\hline $\begin{array}{l}\text { Learning to } \\
\text { understand others }\end{array}$ & Literacy and & $\begin{array}{l}\text { (second and } \\
\text { third grade) }\end{array}$ \\
\hline $\begin{array}{l}\text { through } \\
\text { relationally } \\
\text { oriented reading }\end{array}$ & $\begin{array}{l}\text { imagination } \\
\text { (theory of } \\
\text { mind) }\end{array}$ & 22 students \\
\hline
\end{tabular}

USA
Wordless picture book (Paris \& Paris, 2003);

Reading the Mind in the Eyes Test

(Baron-Cohen et al., 2001); Faux Pas

Test (Baron-Cohen et al., 1999).
Reading training

8 weeks two sessions (45 minutes each) for week
The written responses, interventions and reflections demonstrate the acquisition of the ability to understand others' mind. Significant improvements in recognition of others' emotions $(\mathrm{p}<.001)$, in social imagination during reading $(\mathrm{p}<.001)$, in understanding when someone's feelings are injured $(p<.001)$, in comprehension while listening to a reading $(\mathrm{p}<.001)$ and in narrative skills $(\mathrm{p}<.002)$. 


\author{
Jones et al., 2011 \\ Two-year \\ impacts of a \\ universal \\ school-based \\ social-emotional \\ and literacy \\ intervention: An \\ experiment in \\ translational \\ developmental \\ research
}

USA

Brokamp et al. 2019

The relationship among students' reading

performance, their classroom behavior, and teacher skills

Netherlands

Gordon, 2017

The impact of multicultural

literature on empathy

development in third-Grade

students: A pilot study

USA

Quantitative
Study
Education and
socio-
emotional
development

Primary

School

(third and

fourth grade)

18 schools

1184 students

Experimental:

630 students;

M: 8.17 years

old; $50.6 \%$

female

Control:

554 students;

M: 8.18 years

old; $51.3 \%$

female

\section{Quantitative \\ Study}

Education and socio-

emotional

development

M: 9.25 years old

$51 \%$ female

66 teachers

Primary

School

(third grade)

(Houtveen,

$\begin{array}{cc}\begin{array}{c}\text { Qualitative } \\ \text { Study }\end{array} & \begin{array}{c}\text { Primary } \\ \text { School } \\ \text { (third grade) }\end{array} \\ \begin{array}{c}\text { Intercultural } \\ \text { education and }\end{array} & 17 \text { students }\end{array}$

empathy

$\begin{array}{cc}\begin{array}{c}\text { Morgan et al., } \\ 2012\end{array} & \begin{array}{c}\text { Longitudinal } \\ \text { Quantitative } \\ \text { Study }\end{array} \\ \begin{array}{c}\text { Do poor readers } \\ \text { feel angry, sad } \\ \text { and unpopular? }\end{array} & \begin{array}{c}\text { Reading and } \\ \text { socio- } \\ \text { emotional } \\ \text { adjustment of } \\ \text { children }\end{array}\end{array}$
Primary school
3308
M: 65.50
months
incoming
(5.46 years old)

$48 \%$ female

Experimental: 331

Control: 2977
AVI-test (Jongen \&

Krom, 2009);

Behavior

questionnaire (van

Doorn, 2000);

observation

instrument

Brokamp, \& Smits, 2012).

Reading training

2 years (from third to

fourth grade) al.,1982)

Diagnostic

for Children

Predictive Scales

Behavioral

stem for Children

Kamphaus, 1998);

Social Competence

Conduct

Problems Prevention

ch Group, 1999).

No

intervention

Reading fluency at the beginning of the year is significantly associated with task-oriented behavior $(\mathrm{p}<.001)$, emotional stability $(\mathrm{p}<.05)$ and class behavior $(p<.05)$ at the end of the year. Effective teachers' book introductions are a useful factor to emotional stability $(\mathrm{p}<.05)$.

Reading sessions organizers completed after readings; Motivation to Read Profile Revised (MRP-R) (Malloy, Marinak, Gambrell, \& Mazzoni, 2013); vocabulary probe.

4 weeks

No

intervention Sad/Lonely/Anxious perceptions; SDQ-I (Marsh, 1990);

Reading Test from

ECLS-K (Pollack et al., 2005).

Third grade children who were weak readers $(\mathrm{N}=331)$ subsequently reported feeling angrier $(32 \%)$, sadder $(34 \%)$ or more unpopular $(20 \%)$ than peers who were not weak readers $(10 \%)$; in particular, feelings of sadness, worry and anxiety were frequently improve students' behavior and reported. Girls reported feeling significantly less angry and unpopular than boys. Children who were weak readers in third grade are more than twice as likely to report feeling angry or distracted in fifth grade. 


Beck et. al, 2012
Relationship
between
language
competence and
emotional
competence in
middle childhood
Germany

$\begin{array}{cc}\text { Quantitative } & \text { Primary } \\ \text { Study } & \text { School } \\ & \\ \text { Linguistic and } & \text { 210 students } \\ \text { emotional } & \text { M: } 9,91 \text { years } \\ \text { competence } & \text { old } \\ & 60.9 \% \text { female }\end{array}$

Listing task (adapted from Kusche Affective Interview-Revised, Kusche, Beilke, \& Greenberg, 1988); measures created ad-hoc; storytelling of book; ELFE 1-6 -

German version (Lenhard \&

Schneider, 2006);

Peabody Picture

Vocabulary Test -

German version

(Dunn \& Dunn, 2004).
Kumschick et al., 2014
"Reading and
Feelings": The
effects of a
literature-based
intervention
designed to
increase
emotional
competence in
second and third graders

Germany

Venegas, 2019

"We listened to each other":

Socioemotional growth in

literature circles

USA

Tomé-Fernández
et al., 2019
Values and
intercultural
experiences
through picture
books
Spain

\section{Qualitative Study}

Intercultural education

\author{
Primary \\ School \\ (third and \\ fourth grade) \\ 208 students \\ Experimental: \\ 104 students; \\ M: 9.94 years \\ old
}

Control:

104 students;

M: 7.91 years old

$\begin{array}{cc}\text { Case Study } & \begin{array}{c}\text { Primary } \\ \text { School } \\ \text { (fifth grade) }\end{array} \\ \begin{array}{c}\text { Socio- } \\ \text { emotional } \\ \text { development }\end{array} & 1 \text { student } \\ & \begin{array}{c}10 \text { years old } \\ \text { Female }\end{array}\end{array}$
recordings and feelings, specially created board game
Reading training

8 weeks (two lessons per week of 45 minutes each)

No
intervention

Correlation between receptive vocabulary and knowledge of declarative emotions $(\mathrm{r}=0.45)$, between receptive vocabulary and mixed emotion awareness $(\mathrm{r}=0.44)$; moderate correlation between receptive vocabulary and expressive emotions vocabulary $(\mathrm{r}=0.33)$ and between receptive vocabulary and facial emotion recognition $(\mathrm{r}=0.32)$. Older

children have higher competences for each variable, but in general age and gender do not influence competences in both areas. The hypothesis test confirmed that the model used was effective ( $c=0.99$ ), highlighting that receptive vocabulary and declarative emotional knowledge are the most effective indicators for these competences.

Significant improvements in emotional vocabulary $(\mathrm{p}<0.001)$, explicit emotional knowledge ( $\mathrm{p}<$ 0.001 ) and recognition of masked feelings ( $p<0.001)$. Regarding the treatment effect on the recognition of masked feelings, we found that boys benefited much more than girls $(\mathrm{p}<0.05)$.
Interviews; observations about Grace's interventions and interactions; Grace's role sheets.

Educational laboratory

8 weeks

$$
\begin{gathered}
\text { Primary } \\
\text { School } \\
\text { (fifth grade) } \\
\\
30 \text { students } \\
\text { M: } 10.46 \text { years } \\
\text { old } \\
56.6 \% \text { female }
\end{gathered}
$$

Semi-structured interview created ad-hoc.
Educational
laboratory
Intra-personal skills: Grace improves impulse control and self-confidence through the intervention.

Interpersonal skills: better social awareness after the intervention; good levels of social metacognition in the second half of the literary circle; the intervention fosters Grace's empathy.

Reading stimulated students' empathy towards foreign characters. The study produced qualitative evidence of the usefulness of illustrated books in promoting sensitivity towards intercultural issues. 


\author{
Stutler, 2011 \\ Gifted girls' \\ passion for \\ fiction: The quest \\ for meaning, \\ growth, and \\ self-actualization
}

\section{USA}

$\begin{array}{cc}\begin{array}{c}\text { Qualitative } \\ \text { study }\end{array} & \text { Middle School } \\ & 8 \text { students } \\ \text { Socio- } & \text { Age: } 11-12 \\ \text { emotional } & 100 \% \text { female } \\ \text { development } & \end{array}$

Audio recordings of discussions and interviews with parents; Reading of newspapers;

Researcher's notes; Narrative vignettes.

\begin{tabular}{|c|c|}
\hline $\begin{array}{l}\text { Undheim et al., } \\
2011\end{array}$ & $\begin{array}{c}\text { Longitudinal } \\
\text { Quantitative } \\
\text { Study }\end{array}$ \\
\hline $\begin{array}{l}\text { Emotional and } \\
\text { behavioral } \\
\text { problems among } \\
\text { school } \\
\text { adolescents with } \\
\text { and without } \\
\text { reading } \\
\text { difficulties as } \\
\text { measured by the } \\
\text { youth self-report: } \\
\text { A one-year } \\
\text { follow-up study }\end{array}$ & $\begin{array}{c}\text { Reading } \\
\text { difficulties and } \\
\text { behavioral } \\
\text { problems }\end{array}$ \\
\hline
\end{tabular}

Middle School

Age: $12-14$

$50.7 \%$ female

Experimental: 191

Control: 2273 $\begin{array}{cc}\text { Ad-hoc } & \text { No } \\ \text { questionnaire for } & \text { intervention }\end{array}$

Socioeconomic status (SES);

ad hoc interview

(both created by

researchers); YSF -

Norwegian Version

(Kvernmo \&

Heyerdahl, 1998).

Norway

Chisholm et al.,
2017
Mediating
emotive empathy
with
informational
text: Three
students'
think-aloud
protocols of
"Gettysburg: The
Graphic Novel"
USA
Tijms et al., 2018
Bibliotherapeutic
book club
intervention to
promote reading
skills and
social-emotional
competencies in
low SES
community-base
d high schools: A
randomised
controlled trial

Middle School

Experimental:

40 students;

M: 13.7 years old;

$70 \%$ female

Control:

50 students;

M: 13.6 years old; $76 \%$ female
Case-study

Education and socioemotional development (empathy)

Middle School (eighth grade)

3 students

Age: 13-14

$33.3 \%$ female

A think-aloud interview protocol (VanSledright et al., 2006); assignments.
Students' written

Educational laboratory

3 lessons (60 each)

School Attitude Questionnaire (Smits \& Vorst, 2008).

-emotional development

Bibliotherapy training

12 weeks ( 45 minutes for session, held weekly)
Educational laboratory

1-2 per week:

19 sessions from June
February to minutes

Reading stimulates intellectual, emotional and imaginative growth. Girls experienced moments of "flow" while reading and read for their personal and cognitive growth, they built meanings while examining questions linked to their lives. Emotionally, girls possessed empathic skills and used them to form relationships with characters. They used emotional intensity and intelligence to gain insight about themselves and about others' experiences and feelings.

The total score for problematic behavior increased significantly from $\mathrm{T} 1$ to $\mathrm{T} 2$. The RD group showed a higher number of problems than the non-RD group in both $\mathrm{T} 1$ and $\mathrm{T} 2$ ( $\mathrm{p}<0.001) .53 \%$ of adolescents with DD in T1 also reported them in T2. Externalizing problems also increased among those who did not have DD. There was no difference between those who had received a special education and those who had not, both in T1 and T2. Reading difficulties are a significant predictor of social problems one year later. Those who received special education and experienced DD in T1 showed more social problems than those who did not.

An emotionally meaningful reading experience emerged and these emotions influenced the students' meaning-building processes. They felt empathy for the characters. Researchers argue that students' visual and emotional reading of the graphic novel favored emotional empathy and historical empathy.
The intervention had positive and significant effects on the students' socio-emotional competences ( $p<.05)$ : ability to express oneself, scholastic self-concept and social-relational skills. 
Netherlands

Dylman et al., 2020

Reading habits and emotional vocabulary in adolescents

Sweden

Yussof et al.,
2013
Students' reading
comprehension
performance with
emotional
literacy-based
strategy
intervention
Malaysia
Boatright \&
Allman, 2018
Last year's choice
is this year's
voice: Valuing
democratic
practices in the
classroom
through
student-selected
literature

\section{Quantitative Study}

Emotional intelligence and reading comprehensio n

\section{Case-study}

Education and Empathy

\section{USA}

\section{Pang \& Zhang,} 2011

\section{Reading} intervention for secondary students with hyperactive behaviours in Hong Kong

\section{China}

Effectiveness

of reading in mediating

hyperactive behaviors

\author{
Middle and \\ High School \\ 415 students \\ Experimental: \\ 201 Middle \\ School; \\ M: 14 years \\ old; $53.2 \%$ \\ female; \\ 214 High \\ School; \\ M: 17 years \\ old; $60.3 \%$ \\ female
}

$$
\begin{aligned}
& \text { High School } \\
& 90 \text { students } \\
& \text { M: } 14 \text { years } \\
& \text { old } \\
& \text { Experimental: } \\
& 45 \text { students } \\
& \text { Control: } \\
& 45 \text { students }
\end{aligned}
$$

High School (ninth and tenth grade)

Age: 14-16

\section{Students' written assignments; \\ Researchers' \\ observations.}

\section{Reading \\ Comprehension Test \\ (RCT) constructed \\ by the researchers \\ (Barrett \& Smith,} 1974).

Educational laboratory

1 scholastic

Special

reading

sessions

8 weeks

$$
\text { year }
$$

Reading

training

3 participants from a
Observation grid, camera, questionnaire with closed and open answers, questionnaire and interview on reading habits, interests and difficulties in the task of understanding the text (all created ad hoc); assessment test ad-hoc.
Students showed empathy for the characters, the will to understand their actions and choices. Students approached reading in a reflective and empathetic way, working collectively. Literary circles

fostered cooperation and discussion of books' issues in a protected environment, but were also perceived as too restrictive by students.
After 1st week: comprehension exercises' scores improved slightly.

From $2^{\text {nd }}$ week: the scores increased in line with the average of the class and the average hyperactive behavior decreased significantly. By the $3^{\text {rd }}$ week, the 3 participants scored twice as high as the baseline scores. In the last week, the students showed only a quarter of the initial hyperactive behavior. After the intervention, the number of correct responses of the participants was inversely proportional to the number of unwanted behaviors. The performance in the last 3 weeks was better than the average of the class. In the generalisation phase (interruption of the intervention), performance returned to be similar 


Abdolrezapour \&
Tavakoli, 2012
The relationship
between
emotional
intelligence and
EFL learners'
achievement in
reading
comprehension
Iran
Gerrig et al.,
2016
On the origins of
readers' outcome
preferences

Quantitative
Study
Emotional
reading and
emotional
intelligence
Quantitative Study

Reading and emotional involvement

USA

\author{
High School \\ 63 female \\ students \\ Age: 15-18 \\ years old \\ Experimental: \\ 33 students \\ Control: \\ 30 students
}

High School

Experiment 1: 106

participants;

$59.4 \%$ female

Experiment 2: 110

participants;

$58.2 \%$ female
Self-assessment questionnaire Trait

Emotional

Intelligence

Questionnaire

Adolescent Short

Form (TEIQue-

ASF) (Petrides et

al., 2006).

Likert Scale created ad-hoc.
Reading training

8 weeks ( 24

sessions)

ducational laboratory to that of the pre-treatment phase.

The exposure of EFL students to

literature response activities positively influences their EQ: the experimental group had a statistically significant score compared to the control group $(\mathrm{p}<0.05)$. A difference also emerged between the two groups in the relationship between reading and comprehension activities $(\mathrm{p}=0.000)$ and between emotional intelligence and text understanding $(\mathrm{r}=0.660, \mathrm{p}=0.000)$.

H1. The more readers liked the protagonists of the story, the higher was the measure of "escape rooting" (i.e. the more readers hoped for his escape). Readers who found the protagonist a moral character had higher expectations for his escape $(\mathrm{p}<.01)$, but these expectations were not confirmed by a correlation with sympathy for the character $(\mathrm{p}<.10)$.

$\mathrm{H} 2$. Individual differences in empathy were related to the judgment of sympathy and morality, but the evidence is partial; readers who reported higher levels of empathy tended to report less sympathy for the characters in the text.

$\mathrm{H} 3$. The involvement was positive and significantly correlated to the positive outcome $(\mathrm{p}=<.05)$.

H4. The correlation between empathy and involvement in reading is positive and significant $(\mathrm{p}<.001 ; \mathrm{p}<.05)$.

H5. The correlation between higher involvement and higher enjoyment was confirmed $(\mathrm{p}<.001)$. 


\section{Appendix C}

Table 6. Descriptive Results of Adulthood

\begin{tabular}{|c|c|c|c|c|c|}
\hline $\begin{array}{l}\text { Authors, Title, } \\
\text { Country }\end{array}$ & $\begin{array}{l}\text { Design, } \\
\text { Intervention } \\
\text { area } \\
\end{array}$ & Sample & Evaluation tools & Intervention & Outcomes \\
\hline $\begin{array}{c}\text { McCreary \& } \\
\text { Marchant, } 2017 \\
\text { Reading and } \\
\text { empathy } \\
\text { USA }\end{array}$ & $\begin{array}{l}\text { Quantitative } \\
\text { Study } \\
\text { Education } \\
\text { and empathy }\end{array}$ & $\begin{array}{l}\text { University } \\
696 \text { university } \\
\text { students } \\
\text { Age: } 18-25 \\
80 \% \text { female }\end{array}$ & $\begin{array}{l}\text { Online survey } \\
\text { through Qualtrics; } \\
\text { partial adaptation } \\
\text { of PISA Student } \\
\text { Questionnaire } \\
\text { (Organization for } \\
\text { Economic } \\
\text { Co-operation and } \\
\text { Development, } \\
\text { 2010); a part of } \\
\text { Empathy Quotient } \\
\text { Test (Lawrence, } \\
\text { Shaw, Baker, } \\
\text { Baron-Cohen, \& } \\
\text { David, 2004). }\end{array}$ & $\begin{array}{c}\text { No } \\
\text { intervention }\end{array}$ & $\begin{array}{l}\text { Girls, in comparison to boys, } \\
\text { reported higher levels of empathy, } \\
\text { were involved in more recreational } \\
\text { readings and showed more } \\
\text { appreciation for reading. The } \\
\text { perspective taking ability was } \\
\text { significantly associated with the } \\
\text { appreciation for reading in the } \\
\text { general sample (p <0.005). Girls } \\
\text { (but not boys) who reported higher } \\
\text { levels of reading appreciation also } \\
\text { had higher levels of empathy (p } \\
<0.01 \text { ). In males the amount of } \\
\text { non-recreational reading is related } \\
\text { to less empathy (p <0.05). }\end{array}$ \\
\hline $\begin{array}{l}\text { Pytash } 2013 \\
\text { Using YA literature } \\
\text { to help preservice } \\
\text { teachers deal with } \\
\text { bullying and suicide } \\
\text { USA }\end{array}$ & $\begin{array}{l}\text { Qualitative } \\
\text { Study } \\
\text { Pedagogical } \\
\text { education and } \\
\text { empathy }\end{array}$ & $\begin{array}{l}\text { University } \\
22 \text { pre-service } \\
\text { teachers } \\
\text { Age: } 19-23 \\
95.5 \% \text { female }\end{array}$ & $\begin{array}{l}\text { Interviews, online } \\
\text { discussions. }\end{array}$ & $\begin{array}{c}\text { Educational } \\
\text { laboratory } \\
\\
30-40 \\
\text { minutes } \\
\text { each }\end{array}$ & $\begin{array}{l}\text { Three results: 1) "Previous life } \\
\text { experiences": many participants } \\
\text { knew a person who committed } \\
\text { suicide and expressed their } \\
\text { willingness to understand why it } \\
\text { happened; 2) "the efferent and } \\
\text { aesthetic continuum": the students } \\
\text { used reading to gain practical and } \\
\text { theoretical information on suicide } \\
\text { and bullying issues; 3) "transactions } \\
\text { as future teachers": the students } \\
\text { developed empathy for the } \\
\text { characters in the books and began } \\
\text { to understand the reasons and } \\
\text { feelings that can bring to suicide. } \\
\text { They connected this experience to } \\
\text { their need, as future teachers, to be } \\
\text { empathetic with students. }\end{array}$ \\
\hline $\begin{array}{c}\text { Hoggan \& Cranton, } \\
2015\end{array}$ & $\begin{array}{l}\text { Qualitative } \\
\text { Study }\end{array}$ & $\begin{array}{l}\text { University } \\
131 \text { students }\end{array}$ & $\begin{array}{l}\text { Students' written } \\
\text { reflections. }\end{array}$ & $\begin{array}{l}\text { Educational } \\
\text { laboratory }\end{array}$ & $\begin{array}{l}\text { Three main results: "promoting } \\
\text { change", "new perspectives" } \\
\text { (awareness of new and different }\end{array}$ \\
\hline $\begin{array}{l}\text { Promoting } \\
\text { transformative } \\
\text { learning through } \\
\text { reading fiction } \\
\text { USA }\end{array}$ & Education & $\begin{array}{l}\text { Age: } 20-60 \\
62.6 \% \text { female }\end{array}$ & & & $\begin{array}{l}\text { ways of perceiving the world) and } \\
\text { "promoting critical reflections" } \\
\text { (about themselves and the world). } \\
\text { Other additional results concern: } \\
\text { connections between history and } \\
\text { personal life experiences, emotional } \\
\text { stimulations by reading (and } \\
\text { feelings of being able to express } \\
\text { themselves freely) and } \\
\text { identification of role models in the } \\
\text { book characters. }\end{array}$ \\
\hline Hartung et al., 2016 & $\begin{array}{l}\text { Quantitative } \\
\text { Study }\end{array}$ & $\begin{array}{c}\text { Adult } \\
52 \text { participants }\end{array}$ & $\begin{array}{l}\text { Electrodermal } \\
\text { activity (EDA) } \\
\text { (Matlab R2013a, }\end{array}$ & $\begin{array}{l}\text { Reading } \\
\text { session }\end{array}$ & $\begin{array}{l}\text { Stories with first-person pronouns } \\
\text { lead to higher levels of general } \\
\text { immersion than the stories with }\end{array}$ \\
\hline $\begin{array}{l}\text { Personal pronouns } \\
\text { affect experiential } \\
\text { aspects of literary } \\
\text { reading } \\
\text { Netherlands }\end{array}$ & $\begin{array}{l}\text { Reading and } \\
\text { immersion } \\
\text { experience }\end{array}$ & $\begin{array}{l}\text { M: } 21.4 \text { years } \\
\text { old } \\
57.7 \% \text { female }\end{array}$ & $\begin{array}{l}\text { MathWorks, } \\
\text { Natick, MA, } \\
\text { USA); } \\
\text { Interpersonal } \\
\text { Reactivity Index } \\
\text { (IRI) (Davis, } \\
\text { 1983); Empathy } \\
\text { Quotient }\end{array}$ & 90 minutes & $\begin{array}{l}\text { third- person pronouns }(\mathrm{p}<0.05) \text {. } \\
\text { The pronoun type has no significant } \\
\text { influence on the ranking }(\mathrm{p}=0.06) \text {. } \\
\text { There is a relationship between the } \\
\text { scores of the immersion } \\
\text { questionnaire and the appreciation } \\
\text { of a history (Evaluation: } \mathrm{p}<0.001 \text {; } \\
\text { Classification: } \mathrm{p}<0.001) \text {. People }\end{array}$ \\
\hline
\end{tabular}




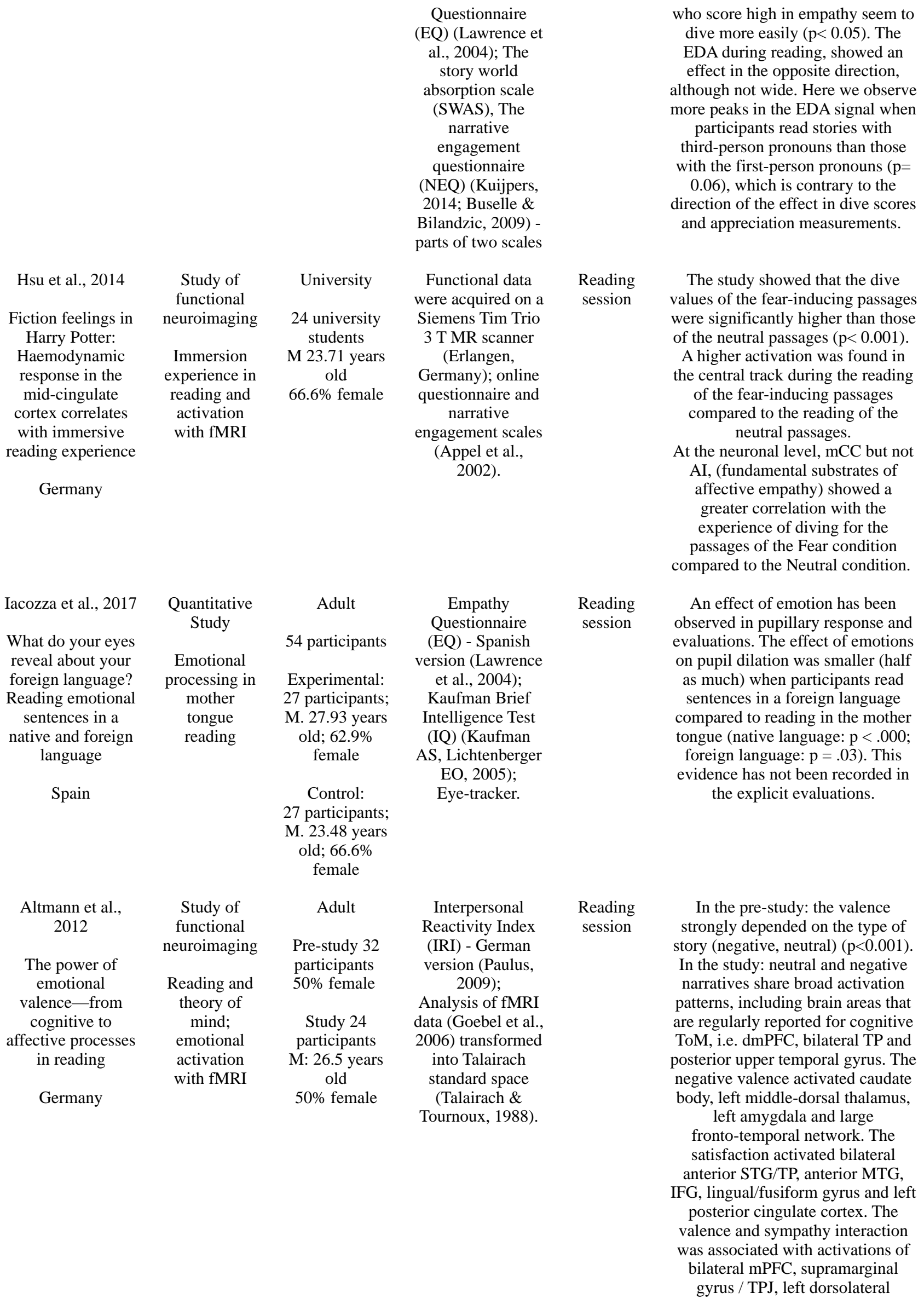




\section{Tabullo et al., 2018 \\ Associations between fiction reading, trait empathy and theory of mind ability}

Argentine

Quantitative
Study
Reading and
empathy,
theory of
mind

University

208 people

Age: 18-59

years old

M: 27.66 years old

$65.86 \%$ female

\section{Koopman, 2015 \\ Effects of \\ "literariness" on emotions and on empathy and reflection after reading}

Netherlands

Junker \&

Jacquemin, 2017

How does literature affect empathy in students?

USA

Quantitative
and
Qualitative
Study
Reading
effects with
foregroundin
g on Empathy
and Affective
responses,
Empathic
understanding

Quantitative
and
Qualitative
Study
Reading and
Empathy

University

142 people

(64.1\%

students)

M: 32.07 years old (age:

17-73);

$74.6 \%$ female

Experimental:

$\mathrm{N}=49$ original

text, $\mathrm{N}=40$

without

imagery, $\mathrm{N}=53$

without

foregrounding

\section{University}

42 students standard analytical writing

assignments, creative writing prompt.

Reactivity Index

Scale (IRI), -

(Davis, 1980,

1983); Traumatic

Pain Inventory

(ITG) - adapted

scale (Boelen et

al., 2003) scale

created ad-hoc.
Reading the Mind in the Eyes Test (RMET)

(Baron-Cohen et al., 2001);

Interpersonal

Reactivity Index

Scale (IRI) (Davis, 1980, 1983).
No

intervention

Reading session prefrontal cortex and

$\mathrm{mPFC}$ Bilateral anterior insula and

right posterior cingulate cortex

showed a stronger coupling with

mPFC for individuals with a

stronger tendency to feel concern for other people $(\mathrm{p}<0.05)$.

Significant associations between

RMET performance and: reading habits $(\mathrm{p}=.03)$ and personal discomfort $(p=.015)$. For trait empathy, fantasy scores were higher in subjects who reported more frequent narrative reading times ( $\mathrm{p}<.001)$ and started recreational reading earlier

$(\mathrm{p}=.014)$, but tended to decrease with age $(\mathrm{p}<.001)$. RMET performance was significantly associated with ART scores within the male group $(\mathrm{p}=.004)$, but this effect was not observed in women.

The association between Mind

Theory performance and narrative print was significant for men $(\mathrm{p}=.002)$ but not for women $(\mathrm{p}=.421)$.

The foreground condition is able to evoke more emotions than other conditions. No difference in emotions after reading $(\mathrm{p}=0.038)$ (significant data for the first group). Empathic understanding is greater in the original text and especially after reading. In general, the degree of reflection depends on the general characteristics of the person,

whether he/she presents empathic traits or not. A general type of reflection is aroused in subjects who also present a greater empathic understanding $(\mathrm{p}=.034)$.
Educational laboratory

1 semester
Cognitive and affective empathy were strongly influenced by the perception of textual difficulty: higher levels of openness, awareness of multiple perspectives, awareness of the cultural framework and affective mental attitude coincided with the perception of a more interesting and intriguing text $(p<.05)$. Significant relationships between empathy and textual difficulty (negative; $\mathrm{p}=.05$ ) and the ability to write (positive; $p$ $<.001$ ). Creative writing tasks stimulate more empathic responses than tasks that require analytical writing ( $\mathrm{p}<.001)$. Empathy did not appear to increase over time.

1) Identity: a lack of interest or attention in identifying the cultures
Educational laboratory
Students' written reflections and 


\author{
Engaging \\ pre-service teachers \\ in read alouds \\ USA

Glenn, 2012
Developing
understandings of
race: Preservice
teachers'
counter-narrative
(re)constructions of
people of color in
young adult
literature
Education
and reading
aloud
48 pre-service teachers

$\begin{array}{cc}\begin{array}{c}\text { Qualitative } \\ \text { Study }\end{array} & \text { University } \\ & \text { 14 English } \\ \text { Intercultural } & \text { preservice } \\ \text { education } & \text { teachers } \\ & 93 \% \text { female }\end{array}$
responses from the preservice teachers
Individual created ad-hoc.

charts about the reading aloud experiences.

20 weeks 2 semesters

Educational laboratory

3-4 weeks (3 days working)
USA

Chamberlain, 2018
The experience of
older adults who
participate in a
bibliotherapy/poetr
y group in an older
adult inpatient
mental health
assessment and
treatment ward

England

\begin{tabular}{|c|c|c|c|}
\hline $\begin{array}{l}\text { Qualitative } \\
\text { Study }\end{array}$ & Adult & $\begin{array}{c}\text { Structured } \\
\text { interview created }\end{array}$ & $\begin{array}{l}\text { Reading } \\
\text { sessions }\end{array}$ \\
\hline $\begin{array}{l}\text { Reading } \\
\text { aloud and } \\
\text { emotional } \\
\text { experience }\end{array}$ & $\begin{array}{l}4 \text { people in the } \\
\text { psychiatric } \\
\text { ward }\end{array}$ & $\begin{array}{l}\text { ad-hoc analized } \\
\text { with } \\
\text { phenomenographi } \\
\text { c protocol. }\end{array}$ & $\begin{array}{c}10 \text { one-hour } \\
\text { sessions } \\
\text { once a } \\
\text { week }\end{array}$ \\
\hline
\end{tabular}

described in the readings; 2 )

Pedagogy: an undeveloped sense efficacy;3) Empathy: the reflections reveal empathy felt for the different cultures represented in the readings and for future students. The readings aloud therefore stimulated empathic reactions.

The reading conducted by teachers, aimed at promoting empathy towards the characters, has generated racial considerations driven by the desire to weave universal connections that unite all human beings.
Being in a reading group had a therapeutic effect; participants were able to empathise with others and share opinions and experiences. This was facilitated by a safe and tolerant environment. Using phenomenographic techniques, the act of reading aloud could be seen as a development of trust in the participants, as an activity through which they could find their voice and identity.

\section{Copyrights}

Copyright for this article is retained by the author(s), with first publication rights granted to the journal.

This is an open-access article distributed under the terms and conditions of the Creative Commons Attribution license which permits unrestricted use, distribution, and reproduction in any medium, provided the original work is properly cited. 